\title{
Om kyrkjebygging og kristning i Rogaland i tidleg mellomalder
}

\author{
ANGUNN SKEISEID
}

Skeiseid, A. 2016. On the establishment of church sites in Rogaland in the High Middle Ages. "The first point in our laws is that we shall bow down to the East and pray to the Holy Christ for good harvests and peace". AmS-Varia 58 , 21-44, Stavanger. ISSN 0332-6306, ISBN 978-82-7760-167-0

This article researches six church sites founded in Rogaland during the early stages of Christianisation in Norway in the High Middle Ages. The areas selected for investigation are the coastal skipreider (administrative units) Time and Klepp in central Jæren, and Jelsa and Suldal in non-coastal Ryfylke. The sites have been assessed in relation to their surroundings, to shed light on the issues of actor, time and choice of location. The investigation revealed two types of church site: sites with proprietary churches erected by a local magnate or middle-ranking landowner, and churches built by the villagers as a collaborative enterprise, in accordance with provisions in the section on church law in Gulatingslova (the Gulating Law) called Kristenretten (Christian Law). The location of church sites relative to older pagan cult sites was assessed, to ascertain to what extent the location of a particular church represented continuity or change. The issue of monumentality appears to have been central in determining the location of proprietary churches, while accessibility seems to have been a consideration that influenced the location of churches built collaboratively by members of the community.It is suggested that Kristenretten was instrumental in spreading Christianity in Norway, in that the provisions on church building and related regulations encouraged the building of churches by a class of middle-ranking landowners.

Angunn Skeiseid, Rogaland County Council, P.O. Box 130, NO-4001 STAVANGER, NORWAY. Phone: (+47) 51921056. E-mail: angunn.skeiseid@rogfk.no

Keywords: High Middle Ages, church location, Christianisation, pagan cult, church builders, central Jæren, non-coastal Ryfylke.

\section{Innleiing}

Ártið er Ingibjargar Káradóttur Prim nóttum eptir krossmessu um várit. Hverr sá maðr rúnar Pessar sér, Dá syngi Pater Noster fyrir sál hennar. Hjalpi Guð Deim er svá gerir $^{1}$ (NIyR III:153, 156).

Sitatet over er frå ei runeinnskrift som var rissa inn på ein planke i den nordre svala på den gamle, no rivne kyrkja på Kleppe på Jæren. Det var biskop Wegner i Stavanger bispedøme som på 1600-talet fekk teikna av innskrifta, som seinare er blitt datert til 1100-talet (NIyR III:153, 156). Kyrkje og innskrift syner at kristendommen iallfall då var komen til Jæren, og at kristne ritual var innarbeidde. Innskrifta fører inn i emnet for denne artikkelen: religionsskiftet, overgangen frå heidendom til kristendom, med utgangspunkt i ei undersøking av kyrkjestader i Rogaland. Artikkelen bygger på - og er ei bearbeiding av - mastergradsoppgåva mi frå 2007 (Skeiseid 2007).

Områda som studien er lagt til, er to ulike landskapsområde i noverande Rogaland fylke, eitt kystnært og eitt fjord- og innlandsstròk. Undersøkinga femner om seks kyrkjestader - stader som har hatt kyrkje i mellomalderen. Desse stadene er lokaliserte i det som i mellomalderen var Haug og Klepp skipreider på midtre Jæren og Jelsa og Suldal skipreider i dei indre delane av Ryfylke. Ingen av kyrkjestadene, som alle opphaveleg hadde trekyrkje, har lenger bevarte restar etter dei tidlege bygga. Det er dermed sjølve staden, og skipinga av denne, som står sentralt i denne undersøkinga.

Det er blitt påvist at kristne idéar og kristen påverknad i stor grad kom til Vestlandet frå Dei britiske øyane. Dermed har det vore rimeleg å gå ut frå at religionsskiftet først gjekk føre seg ute ved kysten, og at kristendommen 
så etter kvart spreidde seg innover i landet (m.a. Sawyer \& Sawyer 1993:103). Val av område er gjort mot ein slik bakgrunn: Klepp og Haug er kystbygder på midtre Jæren som med plasseringa si vender ut mot Nordsjøen og landa og øyane i vest, medan fjordbygda Jelsa og dalføret Suldal ligg inne i Ryfylkefjordane og såleis med større avstand til kysten. Suldal, som ligg lengst inne i Hylsfjorden, har også anslag av å vere ei fjellbygd med grenser, gamle vegar og far som går over fjella til Vest-Telemark og Setesdalen (Bakka 1997:7) og er såleis knytt både til fjorden og til fjellområda i aust.

Folk inne i fjordane må ha vore i kontakt med andre bygdelag lenger ut mot kysten: Den lovpålagde leidangstenesta og den geografiske plasseringa som knutepunkt for ferdsle nord-sør og aust-vest kan ha gjeve opphav til tidleg kontakt med den nye religionen.

Det vil vere av interesse å undersøke om det teiknar seg ulike mønster i ulike deler av Rogaland når det gjeld val av kyrkjestad, og i kva grad eventuelle ulikskapar i eigedomsstruktur og ressursgrunnlag kan ha spela inn.

Sidan det ikkje finst spor av ny kyrkjeleg inndeling i sokn i Olavsteksten av Gulatingslova, og sidan eg i artikkelen elles refererer einast til Olavsteksten ${ }^{2}$, har eg funne det naturleg i valet av objekt for undersøkinga mi å ta utgangspunkt i den adminstrative skipnaden som fanst frå 1024 og i om lag 100 år frametter: skipreideordninga (Fig. 1).

Ein premiss for denne undersøkinga er ein pragmatisk definisjon av «kristning»: Eit område er kristna når kyrkje er reist. Ved å studere plassering av kyrkjestader og samanlikne to område vil det vere mogleg å få kunnskap om kven som var aktørar i kristningsverket, og kva grunnar desse kan ha hatt for å velje å ta del i kristninga ved å reise kyrkje. Saman med bruk av skriftlege kjelder vil tilnærmingsmåten også kunne gje ein indikasjon på tidsspennet for kristning av eit område.

Premissen «eit område er kristna når kyrkje er reist» utelukkar ikkje at den nye trua kan ha slege rot i ei bygd alt før kyrkja var bygd. Ein gravskikk med gravlegging på kyrkjegard kunne til dømes allereie ha vore innført, slik Gulatingslova (G 14) implisitt godkjenner: «Alltid når jordi er vigd, men kyrkja uvigd (...)». Likevel må vi kunne gå ut frå at dess lenger kristningsprosessen var komen i ei bygd, dess meir sannsynleg var det at ei kyrkje vart reist.

Av kristenretten i Gulatingslova går det fram at konge og biskop såg kyrkjereising som eit viktig element i kristningsprosessen. I Olavsteksten vart det slege fast at representantar for ulike samfunnsgrupper kunne vere kyrkjeeigarar. Ei organisering med hovudkyrkjer (G 10), fjordungskyrkjer, åttungskyrkjer, høgendeskyrkjer og heradskyrkjer (G 12) vart lovfest - ei organisering som minner mykje om den som vart nemnd i ei engelsk lov frå 1014 (Spejlborg 2014:73).

I Gulatingslova vart det vidare fastsett kva som skulle skje dersom vedlikehaldet vart forsømt -«um kyrkja brotnar og hyrnestavane fell» (G 12). Det vart vedteke levemåte for prestane (G 15): ved heradskyrkjer etter avtale med bøndene, ved alle andre kyrkjer «som Olav den heilage og Grimkjell biskop etla til på Mostratinget». Det vart lovfest straffer for dei som drog seg unna dei pålagde kyrkjelege tenestene som dåp og kristen gravlegging.

Forutan fylkeskyrkjer, fjordungskyrkjer og åttungskyrkjer skil Gultatingslova (G 12) mellom to slags kyrkjer som ikkje synest å vere hierarkisk rangerte: høgendeskyrkjer (gardskyrkjer) og heradskyrkjer. For høgendeskyrkjene var «einskildmenn» byggherrar, «enten lendmann eller bonde, eller kven det er som byggjer kyrkje» (G 12) (Helle 2001:201). Ei heradskyrkje derimot vart bygd av eit kollektiv kalla «dei som eig kyrkja» (G 12), noko upresist definert som «bøndene» (G 15). Det har vore usemje om lova talar om bøndene i ei bygd som «felag», som kollektive byggherrar (Skre 1998:109ff.), eller om «dei som eig kyrkja» snarare har høyrt til eit jordeigande aristokrati (Brendalsmo 2006). I intensjon kan det sjå ut til at lovteksten refererer til eit kollektiv av bønder: Heradskyrkjer står under eit anna regelverk enn høgendeskyrkjene både når det gjeld vedlikehald (G 12) og tilsetjing av prestar (G 15), og det gjev lite meining om representantar for eitt og same samfunnslaget reiste kyrkje under ulike regelsett, avhengig av korleis dei organiserte seg. Det er også rimeleg å tenkje seg at det vil ha vore skilnader mellom landsdelane: Brendalsmo (2006) si forsking har Trøndelag som nedslagsfelt. «Dei som eig kyrkja» ser eg difor som eit kollektiv av bønder som har teke på seg å reise og halde oppe kyrkje (Helle 2001:201).

Ved å studere lokaliseringa av kyrkjestaden vil det vere mogleg å slå fast med ganske stor grad av visse kva for ei samfunnsgruppe den opphavlege kyrkjebyggjaren representerte. Ei identifisering av kven som bygde vil kunne gje visse haldepunkt for kva tid kyrkja vart reist.

Om vi ser bort frå kongesogene, der det vert fortalt at «Olav bygde kyrkje», ligg det ikkje føre norske skriftlege kjelder som kan fortelje oss kven som organiserte kyrkjebygginga i Noreg, i tida etter at kristenretten var innført, frå 1024 og frametter. Ikkje før i kong Sverre sin tale mot bispane, datert til 1199, får vi eit lite innblikk: «Dei [bispane] krev at vi skal byggje kyrkjer (...)» (Norrøne bokverk nr. 35:29). Dermed må vi gå utanlands for å leite etter parallellar. 


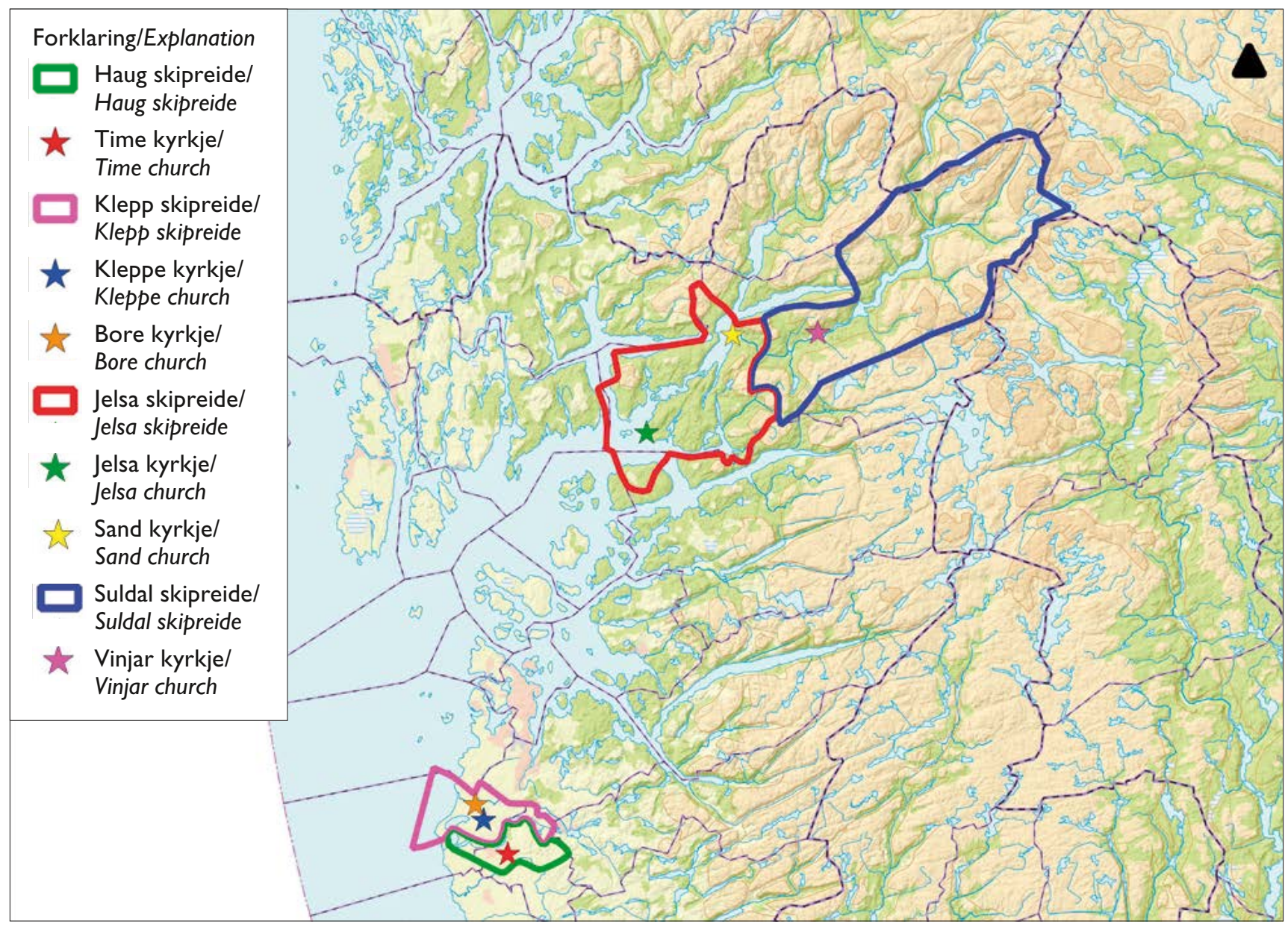

Fig. I. Kart over undersøkingsområda - inndelt i skipreider. Kart: S. Magnell.

Fig. I. Map of the areas for investigation - divided into "skipreider", administrative units. Map by: S. Magnell.

På same måten som i Noreg - Olav Haraldssons biskop Grimkjell kom frå England - var kristninga av Danmark eit resultat av kontakt over Nordsjøen, og i Danmark vart «the earliest phase of church building directed by kings and bishops», ifølgje den danske historikaren Marie Spejlborg (2014:86). Ho utvidar perspektivet når ho skriv at "the close relationship between king and bishop was one of the defining characteristics of the early Scandinavian churches" (Spejlborg 2014:83).

Ein les mellom linjene i Gulatingslova at biskopen var ein mann med makt. Det skulle bøtast til han for mykje; Han hadde med seg «biskops-årmannen» (G 9) som synest å ha hatt eit slag lensmanns-mynde i kyrkjelege saker; når biskopen skulle vigje ei kyrkje, hadde han krav på mat og hus for seg og 15 mann - for hovudkyrkje 30 mann (G 11) - i tre netter (G 14). Det er ikkje usannsynleg at det var biskopen som rådde bygginga av kyrkjer, kan hende gjennom avtalar om dåps- og gravrett, inntektskjelder for ei kyrkje, eller om vigsel av kyrkja. «I kristenretten skin det gjennom at biskopen skulle ha overoppsyn med bygging og vedlikehald av kyrkjer i bispedømmet» skriv historikaren Knut Helle (2001:195).

\section{Landskapsanalyse, retrospektiv bruk av gamle kart ogframstilling av nye}

I denne framstillinga går analysen av staden ut på å studere relasjonen mellom kyrkjestad og gravminne frå jernalder. Kyrkja si plassering med omsyn til om ho er lagd i tilknyting til eit einskilt gardstun eller på meir sentrale stader i bygda er særleg relevant, men også korleis kyrkjestaden er lagd i høve til gamle ferdsleårer og samlingsstader.

Med kristendommen vart gravlegging i større grad enn før sentralisert til éin stad, slik at viktige sider ved kultutøvinga gjekk føre seg på eit avgrensa område: Kristendomsbolken i Gulatingslova gav klare påbod om at ein skulle bygge kyrkje og «setja gard um henne» (G 13), og påbaud at dei døde skulle førast til kyrkja og bli gravlagde i heilag jord (G 23).

Ei tilnærming vil difor vere knytt til spørsmålet kring kultkontinuitet eller kultbrot i topografisk tyding (Gräslund 1992:147). I følgje ein definisjon inneber kultstadskontinuitet at ei kyrkje vart bygd på ein tidlegare, førkristen kultstad (McNicol 1997:13ff). Ein annan går ut på at kultstadskontinuitet ligg føre når ei 
mellomalderkyrkje står nær førhistoriske gravfelt og har namn etter eller ligg på dei gardane som desse gravfelta høyrer til (Müller1991:359). I denne undersøkinga vil kultstadskontinuitet bli definert i ei vid romleg tyding, der ikkje minst visuell kontakt mellom heidensk gravminne og kyrkjestad vil vere eit viktig element $\mathrm{i}$ analysen. Ein avstand på 100 meter mellom mellomalderkyrkje og førkristen grav som uttrykk for nærleik mellom gravhaug og kyrkje har vore det vanlege i arkeologisk forsking dei seinare åra (Brendalsmo \& Sollund 2013:205).

For å vise forholdet mellom kyrkjestaden og heidenske gravhaugar og gravrøyser, gamle gardstun, vegar og sjø, har eg brukt både moderne kart og eldre jordskiftekart, der desse finst.

Før jordskifta var teigblanding karakteristisk for jordbrukslandskapet på Vestlandet. Arkeologar og historikarar meiner at denne eldre gardsskipnaden kan gå langt tilbake i tid (Lunden 2002:359). Jordskiftekart kan difor gi eit detaljert bilete av drifts- og organiseringsformer før jordskiftet og gje indikasjonar på eigedomsforhold og -strukturar i tidlegare tider (Hovstad 1981:20). Den største vinninga ved å bruke slike kart er at gamletunet er teikna inn, noko som er viktig for å kunne seie om kyrkja er reist i tilknyting til eit gamletun. Å bruke desse opplysningane retrospektivt føreset ein viss kontinuitet i tunskipnaden, frå mellomalder og fram til utskiftinga, men for Sør-Vestlandet sin del peiker tunkontinuitet seg ut som vanleg der dette har vorte granska (Øye 2002:286ff.).

No er det likevel slik at det ikkje finst jordskiftekart for alle gardane som har kyrkje i mine undersøkingsområde. Der dette har vore tilfellet, har eg brukt kjelder frå Statsarkivet i Stavanger som gir opplysningar om jordskifte og tunplassering. Lokale gardssoger kan somtid òg gi opplysingar om lokaliseringa av gamletunet (jf. Foldøy 1967).

Når det gjeld gamle ferdsleårer er det sannsynleg at hovudvegen gjennom ei bygd opphaveleg gjekk innom kvar gard. Etterkvart som talet på busetnadseiningar auka, har ein knytt desse til hovudvegen med sidevegar. Vi må anta at vegane i vikingtid og i mellomalder i stor grad har følgt trasear som går langt tilbake i tid (Smedstad 1988:137ff.)

Kyrkjestadene si eventuelle plassering nær ein kjend lokal tingplass kan gi indikasjonar på om ein har lagt vekt på å leggje kyrkjene nær etablerte møteplassar, samt vere uttrykk for at ein tinglyd kan ha vore kyrkjeeigar. Gulatingslova nemner tre tingnivå - fjordung, fylke og lagdøme, som den øvste domsmakta (Helle 2001:76ff.). Lova nemner ikkje mindre lokale rettseiningar; like fullt kan det ikkje vere tvil om at lova føreset slike lokale ting heradsting eller bygdeting - som kan ha omfatta eit mindre område enn fjordungen (Helle 2001:78ff.). I Rogaland har det vist seg problematisk å lokalisere fjordungstinga (jf. Steinnes 1974), men òg dei mindre bygdetinga, noko som gjer at vi må ta visse atterhald når vi skal sjå kyrkjestadene i samanheng med såkalla "gamle samlingsstader». Tingstadene vil såleis berre bli brukte som indikasjonar på at det er kan ha funnest ein eldre samlingsstad før kyrkjestadene vart etablerte. «Ting-» som ledd i lokalitetsnamnet reflekterer nok likevel ein historisk realitet.

\section{Retrospektiv metode og bruk av eldre skriftlege kjelder} I forsøket på å finne ut kven - det vil seie kva for gruppe i samfunnet - som kan ha reist kyrkje, er kunnskap om gardane sin tidlegare økonomiske status i bygdelaget viktig. Slike opplysningar er ikkje å finne i samtidskjelder frå mellomalderen, men eigedomskjelder frå tidleg nytid kan peike bakover i tid og avdekke tendensar i materialet.

Opplysningar om ein gard si landskyld - leigeavgifta leiglendingen ytte til jordeigaren - er ei nyttig kjelde til informasjon, i og med at landskylda var eit uttrykk for ein gard sin bruksverdi og økonomiske bereevne (Andressen [1980] 1991:44) og indirekte for maktforholda i lokalsamfunnet. Skattematrikkelen frå 1647 er den eldste bevarte skriftlege kjelda som gir eit samla oversyn over landskylda for gardane i alle skipreider.

Ein føresetnad for å kunne bruke matrikkelen retrospektivt er at det har vore stor grad av stabilitet i ein gard si produksjonsevne og i eigedomsmessige forhold frå tida då kyrkjene vart reiste til matrikkelen vart skriven. Han må difor nyttast med varsemd. Gardar har vakse ved nyrydjing og minka ved oppdeling; kyrkjegods vart konfiskert og jord omfordelt ved reformasjonen; ein gard kan ha hatt inntekter frå andre gardar 500-600 år tidlegare.

\section{Studium av namn på gardar som har kyrkjestad}

Stadnamn, i hovudsak gardsnamn, kan også kaste lys over ein gard sin alder og status. I den grad det let seg gjere i mine undersøkingsområde, vil namna på dei gardane som har kyrkje bli vurderte etter om dei har gjeve namn til einingar utanom garden, til dømes til bygda, skipreida, eller seinare soknet som han ligg i. Gardsnamna har blitt nytta i forsøk på å kaste lys over ein gard si busetnads- og økonomiske historie. Gardsnamn kan saman med topografiske og økonomiske opplysningar gje indikasjonar på gardar sin alder og sosial og politisk status i eldre tid (Andersen 1977:19, Særheim 2014:49).

\section{Dateringar}

Det er som regel vanskeleg å slå fast nøyaktig kva tid ei kyrkje vart reist. Ei tilnærming er å undersøkje kva tid 
den heidenske gravskikken med haug- og røyslegging tok slutt. Det vil kunne gje ei terminus post quem-datering, kva tid kyrkja tidlegast kan ha blitt reist. Føresetnaden er at gravene er arkeologisk undersøkte, og at gravgodset let seg datere.

På den andre sida kan terminus ante quem-dateringar, ut frå opplysningar i Diplomatarium Norvegicum, seie noko om kva tid kyrkja seinast har blitt reist. Metode for meir presise dateringar er vanskeleg å finne - i dei aller fleste tilfella vil det vere eit spenn mellom "tidlegast reist" og "seinast reist".

\section{Kyrkjestadene i landskapet}

Ulike faktorar har lege som premiss for plassering av dei nye kultstadene, som busetnad, maktforhold, forholdet til førkristne gravminne, tilgjenge, visuell kommunikasjon og synlegheit.

Vart kyrkjestadene etablerte i relasjon til eldre rituelle stader, ved graver eller som utviding av eit gravfelt? Eller er det snarare slik at kyrkjene vart plasserte utan nokon relasjon til den gamle kulten?

Vart dei nye kultstadene lagde nær kommunikasjonsmessige knutepunkt eller ved kjende samlingsplassar, som tingstader, eller vart dei oppførte på i denne samanhengen ny grunn? Kommunikasjonsforholda kring kyrkjestaden, gode ferdsleårer eller fråvere av slike og grad av sentral plassering vil kunne fortelje i kva mon ein kyrkjestad er blitt vald for å gjere kyrkja lettast mogleg tilgjengeleg for folk i lokalsamfunnet.
Kyrkjebygginga som fann stad i samband med religionsskiftet, kan også ha hatt knytt til seg aspekt som utøvd og stadfest makt. Eg vil difor sjå om kyrkjestadene vart plasserte nær tunet på gamle storgardar, eller om plasseringa heller var uttrykk for eit bygdefellesskap.

Kyrkjer skulle signalisere ein bakanforliggande bodskap om ein stor Gud, men vi må tenke oss at sjølve kyrkjebygga som vart reiste i den første tida var små trekyrkjer som gjerne ikkje skilde seg så mykje ut frå dei andre bygga på ein gard eller i ei bygd. I så fall måtte kan hende staden vere desto meir synleg og dominerande. Er kyrkjene plasserte på stader som har ein monumental karakter, eller ligg dei på stader som er meir innovervende og vender seg til den næraste busetnaden - privatsfæren?

I det følgjande presenterer eg dei kyrkjestadene eg har valt som det empiriske grunnlaget for denne undersøkinga.

\section{Haug skipreide}

I Haug skipreide er det éin kyrkjestad, Time (Fig. 1). Skipreida (Haugs skipreiða) er nemnd første gong i 1445 (DN III, 786) og har namn etter Hauge-garden (Steinnes 1974:87, Særheim 1987:217, Særheim 2014:56).

\section{Time kyrkje}

Gard: Øvre Time, gnr. 17, bnr. 19, Time kommune.

Nemnt første gong: Pyminæs kirkiu, DN IV 650, 1395. Det er nemnt ein "prostr á Pimini" DN IV 189, 1329.

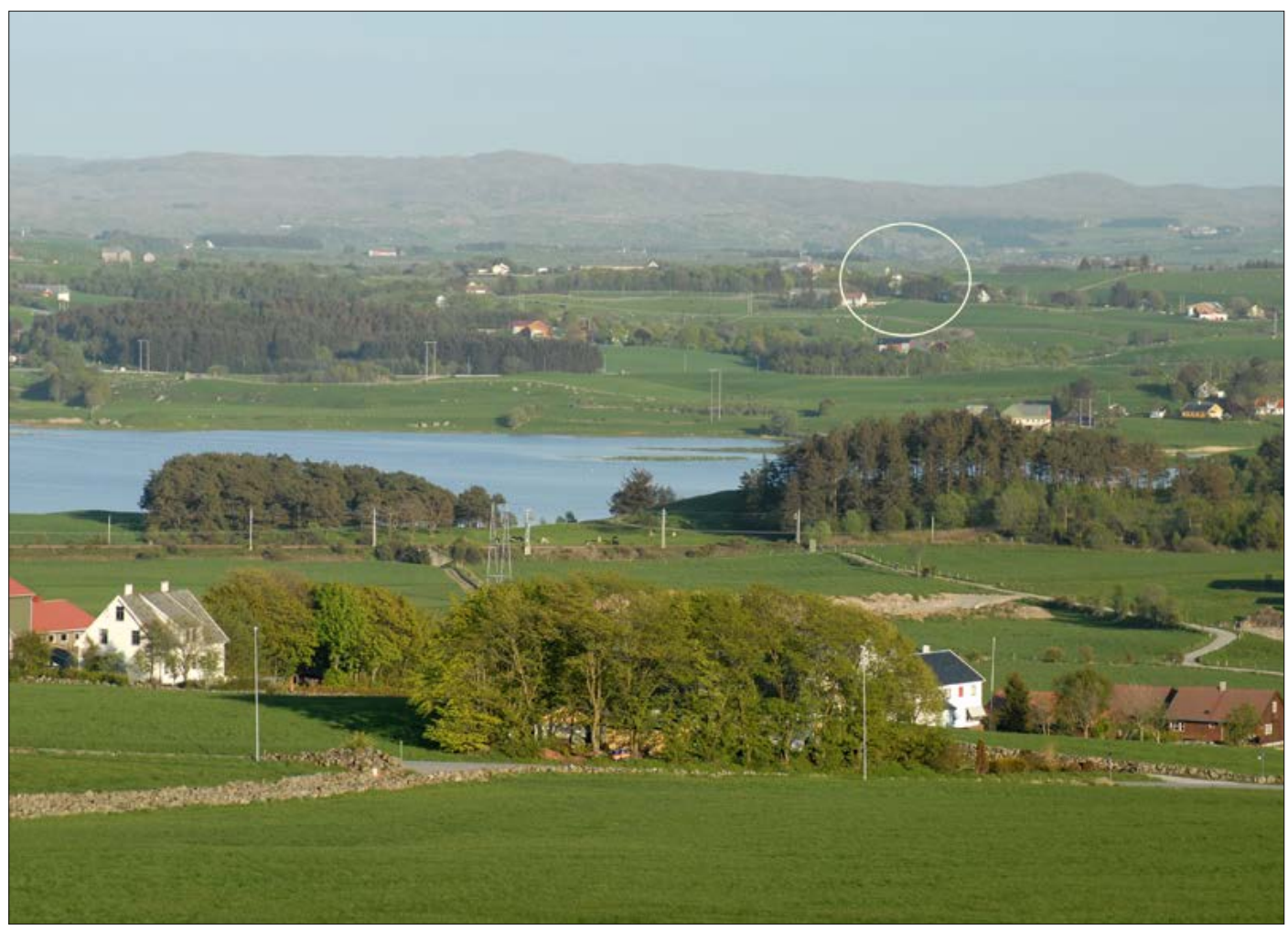

Fig. 2. Time kyrkjestad sett mot søraust. Foto: $\mathrm{G}$. Tengesdal. Fig 2. Time church site seen towards south-east. Photo: $G$. Tengesdal. 
Nedlagd eller flytta: Nei, ingen opplysningar som tilseier det.

Namn på kyrkjestaden: Time, gards- og seinare soknenamn.

Lokalisering og topografi: Kyrkjestaden på Time ligg på eit høgdedrag nesten på grensa mellom to særeigne landskapstypar - eit hovudsakleg flatt morenelandskap og det noko stigande fjell- og knauslandskapet i aust på HøgJæren (Fig. 2).

Omkringliggjande kulturminne: Det er ingen gravminne i nær tilknyting til kyrkjestaden (Fig. 3). I aust-søraust og i sør er der fleire gravminne, både i form av gravhaugar og -røyser frå jernalderen. Mange har visuell kontakt med kyrkjestaden.

Kyrkjestaden $i$ forhold til veg, elv/vatn, tun og tingplass: Bygdevegen går gjennom det gamle tunet på Time, deler seg i to ved kyrkja og omkransar henne. Det gamle tunet ligg i 20-30 meters avstand vest for kyrkja. I nordvestleg retning ligg Frøylandsvatnet i ein avstand på 1,9 km. Både på garden Hauge og på Lye (Prestegarden) skal det ha vore tingplassar i gammal tid (Birkeli 1973:140, Steinnes 1974:87). Tingstaden på Hauge låg nordvest for Time kyrkjestad, med visuell kontakt stadene imellom. Lye låg om lag $10 \mathrm{~km}$ aust for kyrkjestaden, utan noko visuelt samband til denne.

Henvending: Kyrkjestaden henvender seg i alle retningar. Unnataket må vere eit noko innsnevra utsyn mot nordaust. Når ein tek omsyn til at Jæren var skoglaust i vikingtid, må også innsynet ha vore særs godt.

Vurdering av kyrkjestaden: Kyrkjestaden ligg i nær tilknyting til gardstunet på Time og må ha vore svært synleg i landskapet på grunn av den monumentale karakteren. Det er ingen gravminne i nær tilknyting til garden og kyrkjestaden. Sentrale samlingsplassar, som tingstadene på Hauge og Lye, låg båe relativt langt borte. Når det gjeld kommunikasjonar går den gamle bygdevegen like ved kyrkjestaden. Det vil ha vore mogleg å komme seg til kyrkja med båt på Frøylandsvatnet, trass $\mathrm{i}$ at avstanden frå vatnet til kyrkja er på nesten $2 \mathrm{~km}$.

\section{Klepp skipreide}

I skipreida finst to kyrkjestader, Klepp og Bore. Kyrkjestaden på Bore ligg lengst nord i skipreida, medan Klepp kyrkjestad ligg noko meir midt i (Fig. 1). Klepp skipreide (Klepps skipreiða) er nemnd første gong i 1386 (DN IV 531 og 532). Saman med Haug utgjer denne skipreida det sentrale Jæren.

\section{Klepp kyrkje}

Gard: Kleppe, gnr. 1, bnr. 126, Klepp kommune.

Nemnd første gong: Klaps kirkiu, DN I 70, udatert (ca. 1280).

Nedlagd eller flytta: Flytta. Den gamle kyrkjestaden på Kleppe skal ha lege $100 \mathrm{~m}$ nord for den noverande kyrkja, og det finst opplysningar om at det stod ei stavkyrkje her så seint som på 1600-talet (Særheim 1996:24). Den nye kyrkja vart bygd på ny stad i 1846 .

Namn på kyrkjestaden: Kleppe, namnet på garden, og Klepp, namnet på kyrkjestaden, skipreida, og soknet, av gno. kleppr (m).

Lokalisering og topografi: Den gamle kyrkja har lege på eit høgdedrag som slakar utover i vest (Fig. 4). Bygda

Fig. 3.

Oversiktskart

Time kyrkje-

stad. Kart: S.

Magnell.

Fig. 3. Map of

Time church

site. Map by: $S$.

Magnell.

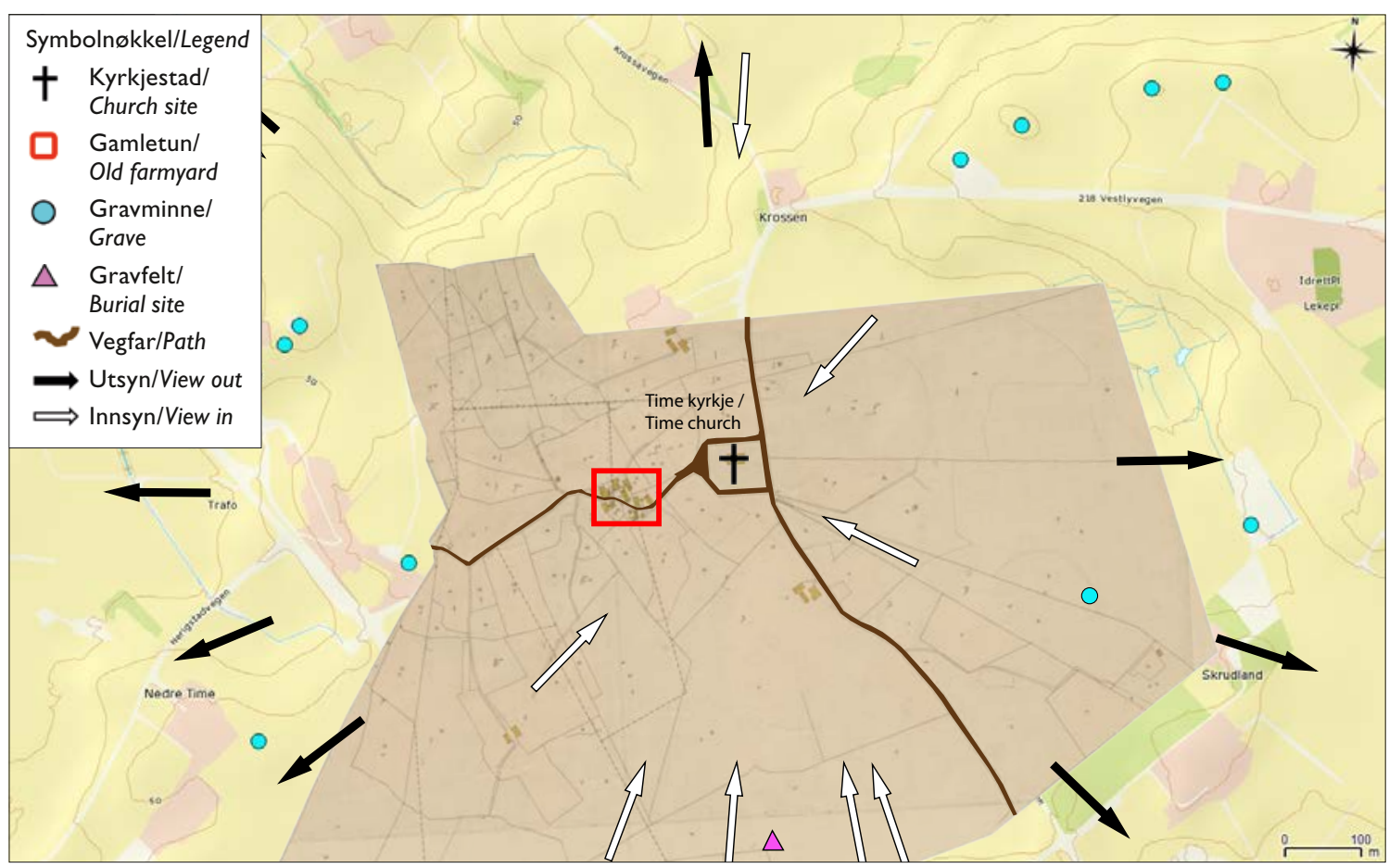




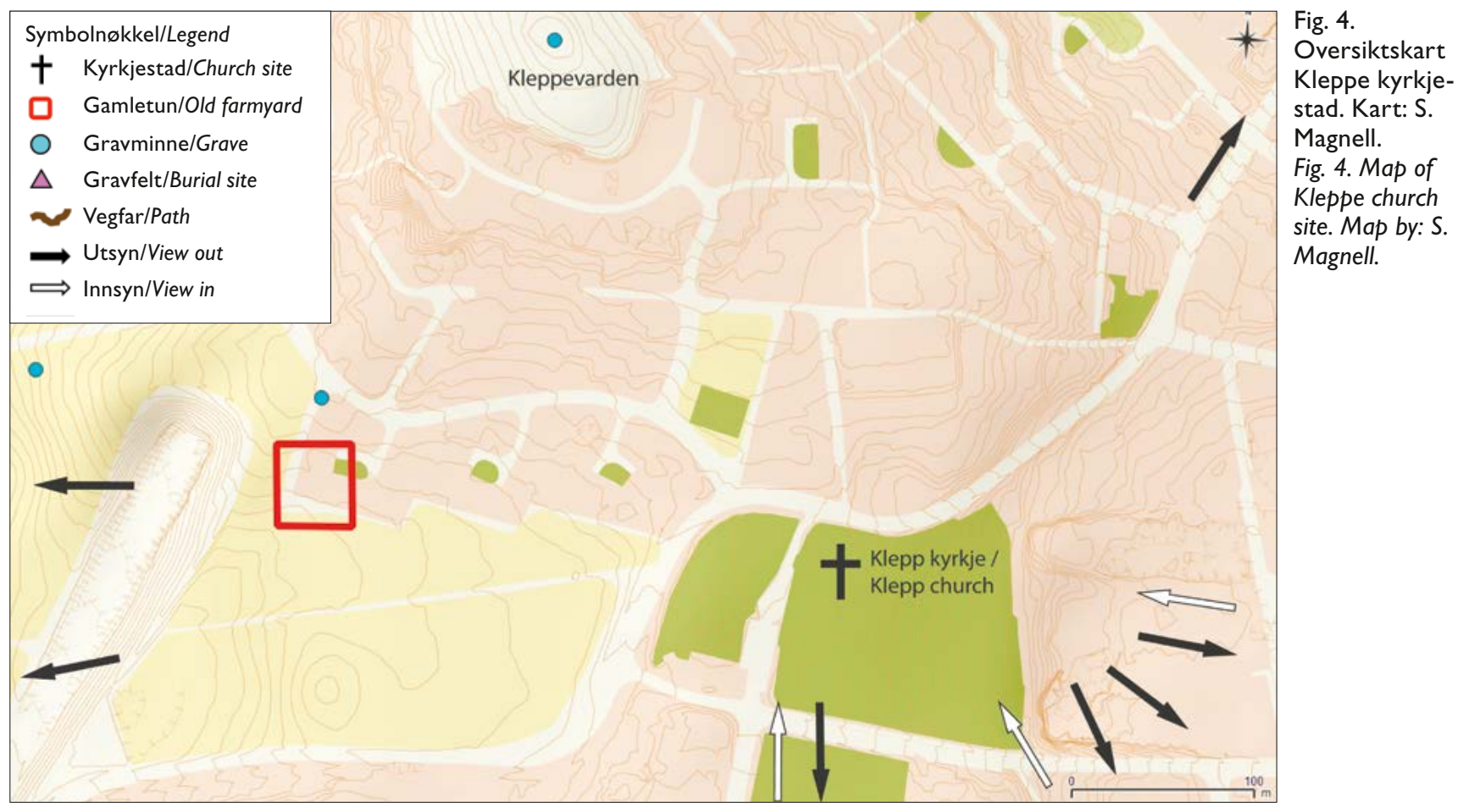

Kleppe har vakse fram nedanfor høgdedraget og kyrkjestaden, i aust og søraust.

Omkringliggande kulturminne: Kleppevarden ligg 230 $\mathrm{m}$ nordvest for den gamle kyrkjestaden. Dette er ein stor gravhaug frå eldre bronsealder (1800-1000 f.Kr.), som ruvar i landskapet, med ein omkrins på $35 \mathrm{~m}$ i diameter og ei høgd på $2 \mathrm{~m}$.

I 1639 fortel biskop Wegner at det fanst ein runestein med innrissa kross på Klepp kyrkjegard (Birkeli 1973:106). Steinen er føreslått datert til 1000-talet eller tidlegare (Birkeli 1973:107 med referanse).

Kyrkjestaden $i$ forhold til veg, elv, tun og tingplass: Gamletunet på Kleppe har lege om lag 100 m vest for kyrkjestaden. Det er inga farbar elv eller noko vatn i nærleiken av kyrkjestaden. Truleg har Tinghaug i sørvest vore næraste tingplass.

Henvending: Kyrkja har henvendt seg i alle retningar, i og med at ho har lege på eit særskilt markert høgdedrag i landskapet. Utsynet har vore særs godt mot aust, nordaust, sør og sørvest, men i nordvest har Kleppevarden hindra innsyn og utsyn. Mot sørvest kan ein sjå til krossstaden på Hauge.

Vurdering av kyrkjestaden: Kyrkja låg ikkje langt frå gamletunet på Kleppe. Staden har ein monumental karakter med vidt utsyn i dei fleste retningar. Det finst ikkje graver nær kyrkjestaden, og han er heller ikkje plassert nær ein tingstad.

\section{Bore kyrkje}

Gard: Vestre Bore, gnr. 44, bnr. 10, Klepp kommune.
Nemnd første gong: Borðu sokn, DN III 132, 1322.

Nedlagd eller flytta: Ja, den gamle kyrkja vart riven og i 1891 vart ny bygd 1,5 km nordaust for den gamle kyrkjestaden, på nabogarden Austre Bore. På kyrkjegarden, som er gjerda inne av ein kraftig steinmur, er der fem gravsteinar med runeinnskrifter frå mellomalderen og svake spor etter den gamle kyrkjetufta (Sør-Reime 2003:21).

Namn på kyrkjestad: Bore, av gno. Borða (f), er eit gammalt gards- og bygdenamn. Seinare vart det også soknenamn.

Lokalisering og topografi: Kyrkjegarden og den gamle Bore-kyrkja låg på eit lite høgdedrag, om lag 26 m over Bore-markene i nordvest og nordaust (Fig. 5 og 6). Marka som kyrkja har lege på heiter "Kyrkjeågeren" (Rønneseth 2001:140). Figgjoelva ligg i nordaust. Om lag 2 km i luftlinje i vestleg retning er havet.

Omkringliggande kulturminne: Ein gravhaug, datert til yngre jernalder, ligg like ved kyrkjegardsmuren i sør. Der er to rundhaugar frå jernalder i søraust, på garden Austre Bore, som har visuell kontakt med den gamle kyrkjestaden på Vestre Bore. Det har også vore fleire gravhaugar frå jernalder sør for kyrkjestaden på Vestre Bore.

Kyrkjestaden $i$ forhold til veg, elv, tun og tingplass: Kyrkjestaden ligg like aust for eitt av dei to gamle tuna på Bore. Bygdevegen går om lag $30 \mathrm{~m}$ sør for kyrkjestaden. Orrevatnet ligg om lag 1,2 km sørvest for kyrkjestaden.

Henvending: Kyrkjestaden er svært godt markert i terrenget, særleg sett frå nord, nordvest og nordaust. I søraust er det mogleg å sjå til Kleppevarden på Kleppe. 
Vurdering av kyrkjestaden: Kyrkjestaden ligg i tilknyting til tunet på Bore-garden. Staden har ein monumental karakter, med godt inn- og utsyn. Det er mange gravminne rundt om på garden, også ein haug tett inntil kyrkjegardsmuren.

\section{Jelsa skipreide}

I skipreida finst to kyrkjestader frå mellomalder, Jelsa og Sand. Båe har ei sentral plassering, men i ulike delar av skipreida (Fig. 1). Jelsa skipreide (Jalsa skipreiða) er første gong nemnd i 1361 (DN IV 421). Skipreida femnde om nesten heile Ropeidhalvøya, Erfjord, Sand og somme av gardane på øya Ombo. Ho er om lag tre gonger så stor i utstrekning som kvar av dei to ovannemnde skipreidene på Jæren.

\section{Jelsa kyrkje}

Gard: Berg (Prestegarden)/Sandane, gnr. 139, bnr. 64, Suldal kommune.

Nemnd første gong: Jalsa kirkiv, DN I 70, udatert (ca. 1280).

Nedlagd eller flytta: Nei, det finst ingen kjelder som tilseier det.

Namn på kyrkjestad: Jelsa av gno. Jalsi (m). Jelsa er namnet både på ein gard, ei bygd, skipreida og seinare soknet.
Fig. 5. Bore gamle kyrkjestad sett mot søraust. Foto: A. Skeiseid.

Fig. 5. Bore old church site seen towards south-east. Photo: A. Skeiseid.
Fig. 6. Oversiktskart Bore gamle kyrkjestad. Kart: S. Magnell. Fig 6. Map of Bore old church site. Map by: S. Magnell.
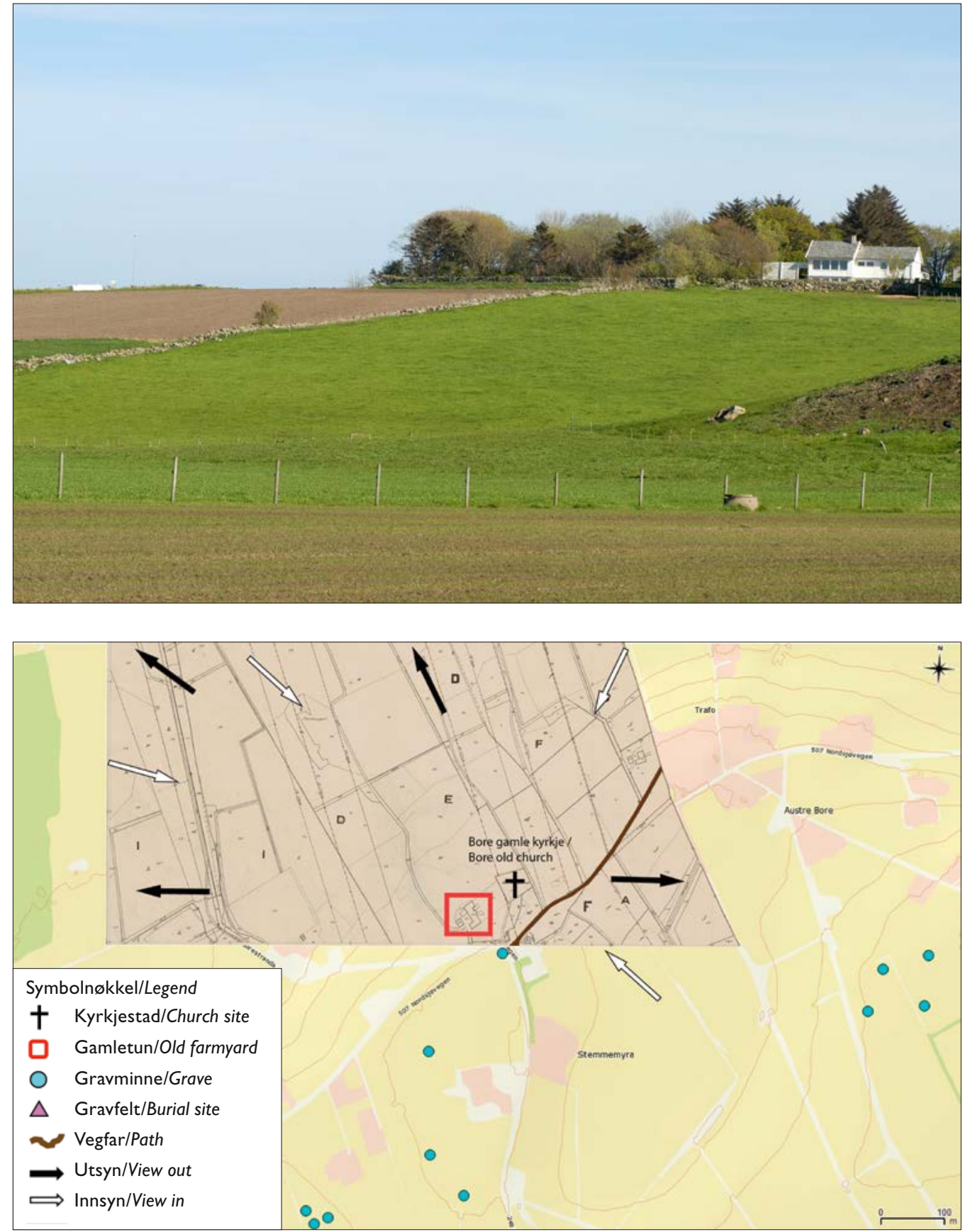


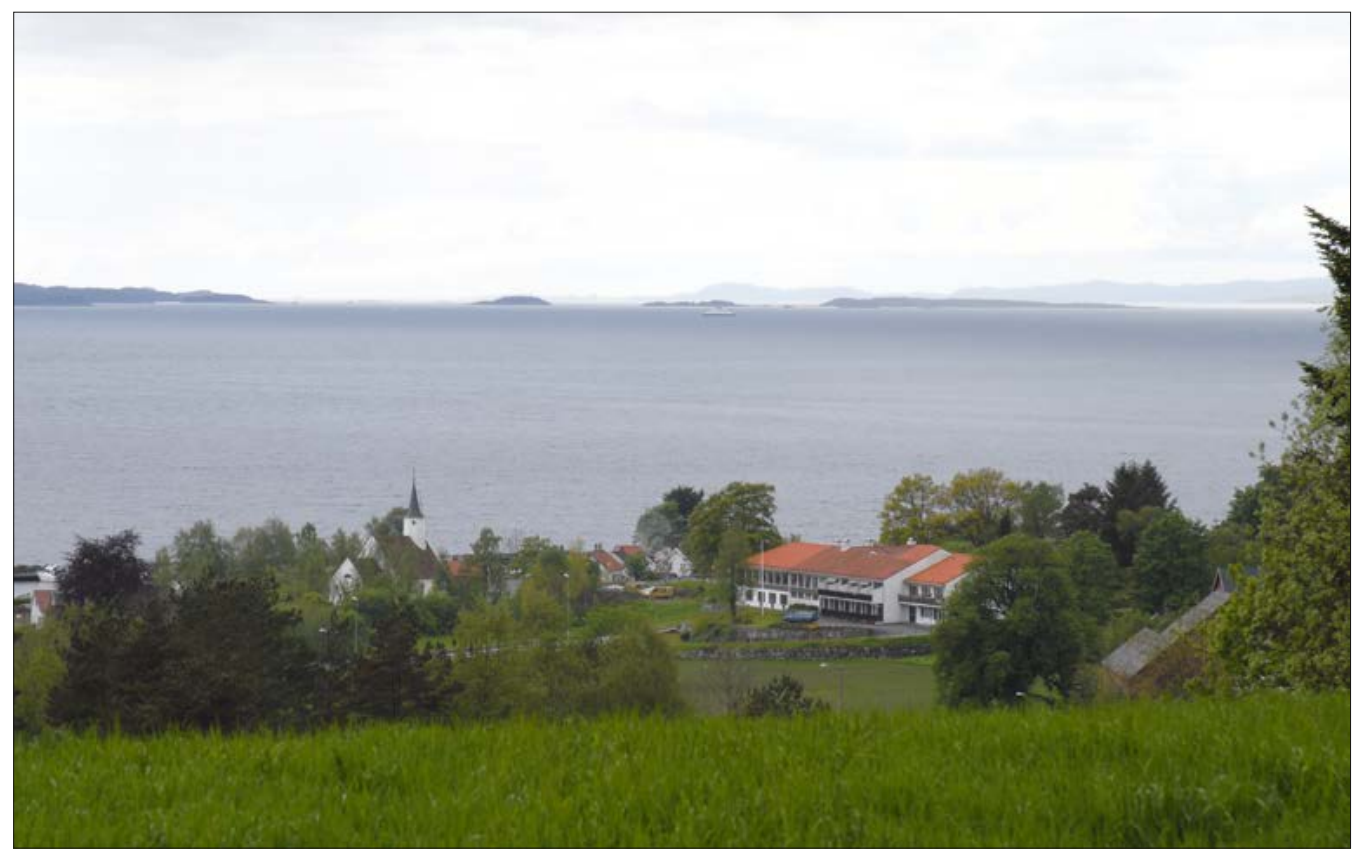

Fig. 7. Jelsa kyrkjestad, mot sørvest. Heilt til høgre, bak nokre trær, kan ein skimte noko av taket (grått) på ein driftsbygning på garden Jelsa. Foto: G. Tengesdal. Fig. 7. Jelsa church site, seen towards south-west. To the right, behind some trees one can see parts of the roof on the barn at Jelsa farm. Photo: $G$. Tengesdal.

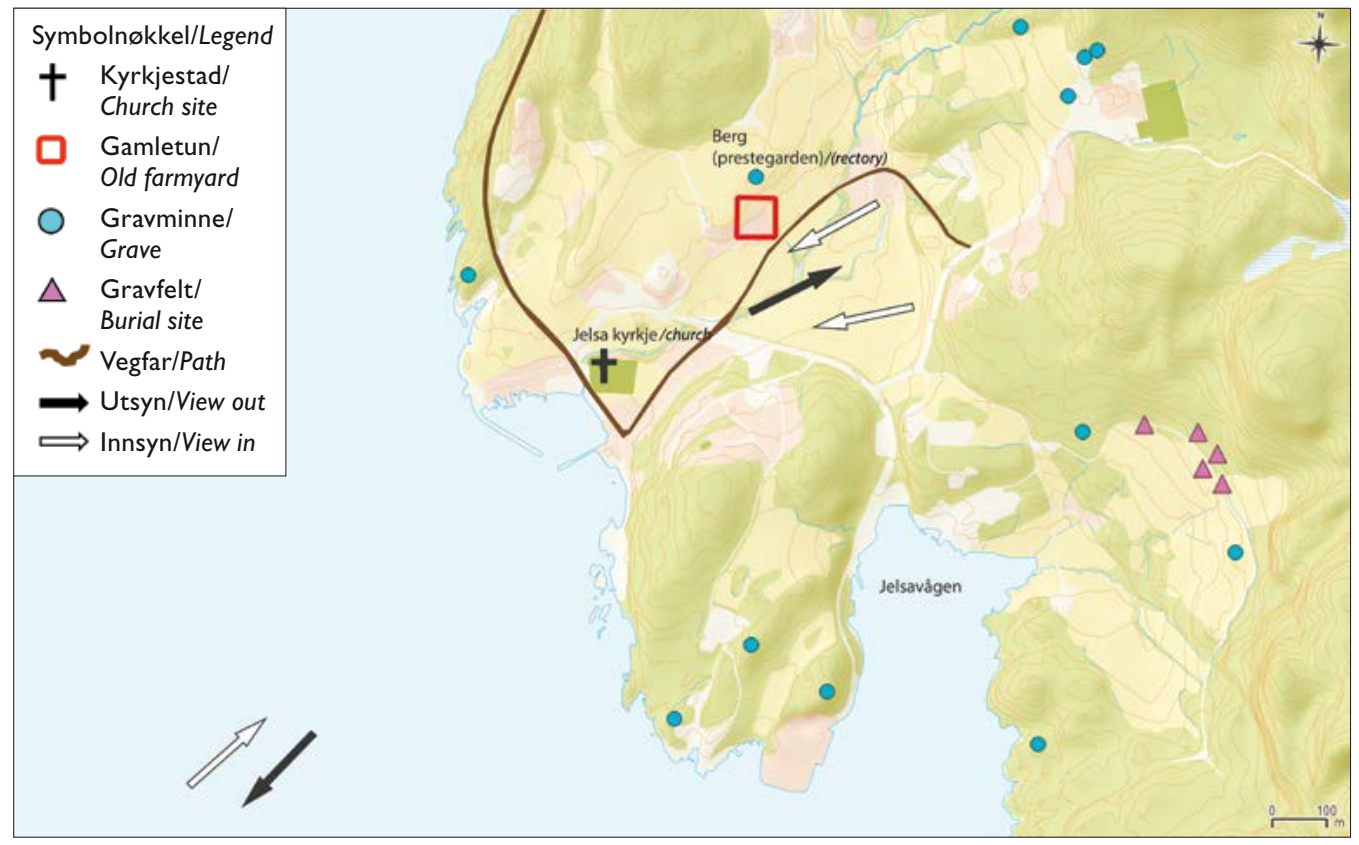

Fig. 8. Oversiktskart Jelsa kyrkjestad. Kart: S. Magnell.

Fig. 8. Map of Jelsa church site. Map by: S. Magnell.

Lokalisering og topografi: Kyrkjestaden ligg sentralt til i bygda. Om lag $30 \mathrm{~m}$ mot vest er fjorden. Mot aust er det stort sett eit flatt sletteterreng, med stigningar lengst i aust (Fig. 7 og 8).

Omkringliggjande kulturminne: På sletta ved kyrkja har det så seint som fram til midten av 1800-talet lege nokre gravhaugar. Det skal også ha stått ein stor haug nær kyrkja (Foldøy 1967:517 med referanse, Næss 1970:Top. ark, AM, UiS). Det er i dag ingen synlege fornminne ved og rundt kyrkjestaden.

Kyrkjestaden i forhold til veg, elv/vatn, tun og tingplass: Kyrkjestaden ligg som nemnt nær sjøen. Det gamle tunet på grannegarden til Prestegarden, Jelsa, ligg om lag 400 m mot nordaust, prestegardstunet endå lenger vekke. Asgaut Steinnes har sannsynleggjort at Hebnes kan ha vore møtestad for fjordungstinget ${ }^{3}$ i det nordaustlege området nord for Boknafjorden (Helle 2001:77 med referanse, Steinnes 1930-33:181ff., Steinnes 1974:93ff.). Helle (2001:77) går ikkje mot dette, men understrekar at vi i praksis ikkje høyrer om noko fjordungsting på denne staden. Hebnes og Jelsa har visuell kontakt, men dei er skilde av fjorden.

Henvending: Kyrkjestaden henvender seg hovudsakleg til fjorden i vest, men også mot det stigande terrenget i aust. Det er eit flatt, men etter kvart stigande, englandskap bakom kyrkja i aust og nordaust, som gjev godt innsyn ned mot kyrkja og fjorden i vest (Fig. 8). 
Fig. 9. Sand kyrkjestad mot søraust. Den gamle kyrkja låg på "Kyrkjehauen". Til venstre, ved grå bygning, låg gamletunet på Sandsgarden Foto: A. Skeiseid.

Fig. 9. Sand church site towards south-east. The old church was situated at "Kyrkjehauen". To the left, where there is a grey building, was where the old farmyard at Sand farm was situated. Photo: A. Skeiseid.

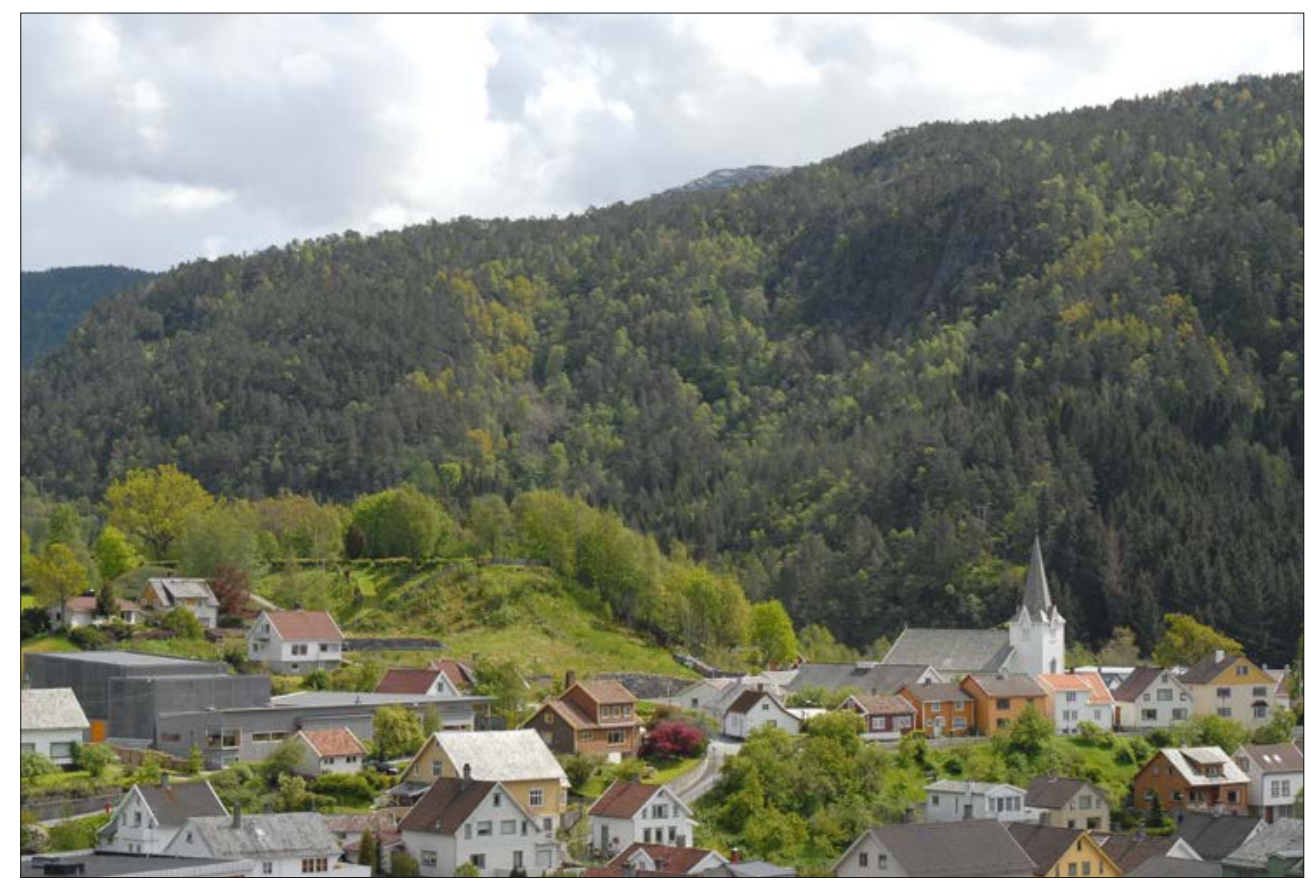

Fig.I0. Utsyn frå den gamle kyrkjestaden på Sand. Biletet er teke mot nordvest. Foto: A. Skeiseid. Fig. I0. View from the old church site at Sand. Towards north-west. Photo: A. Skeiseid.

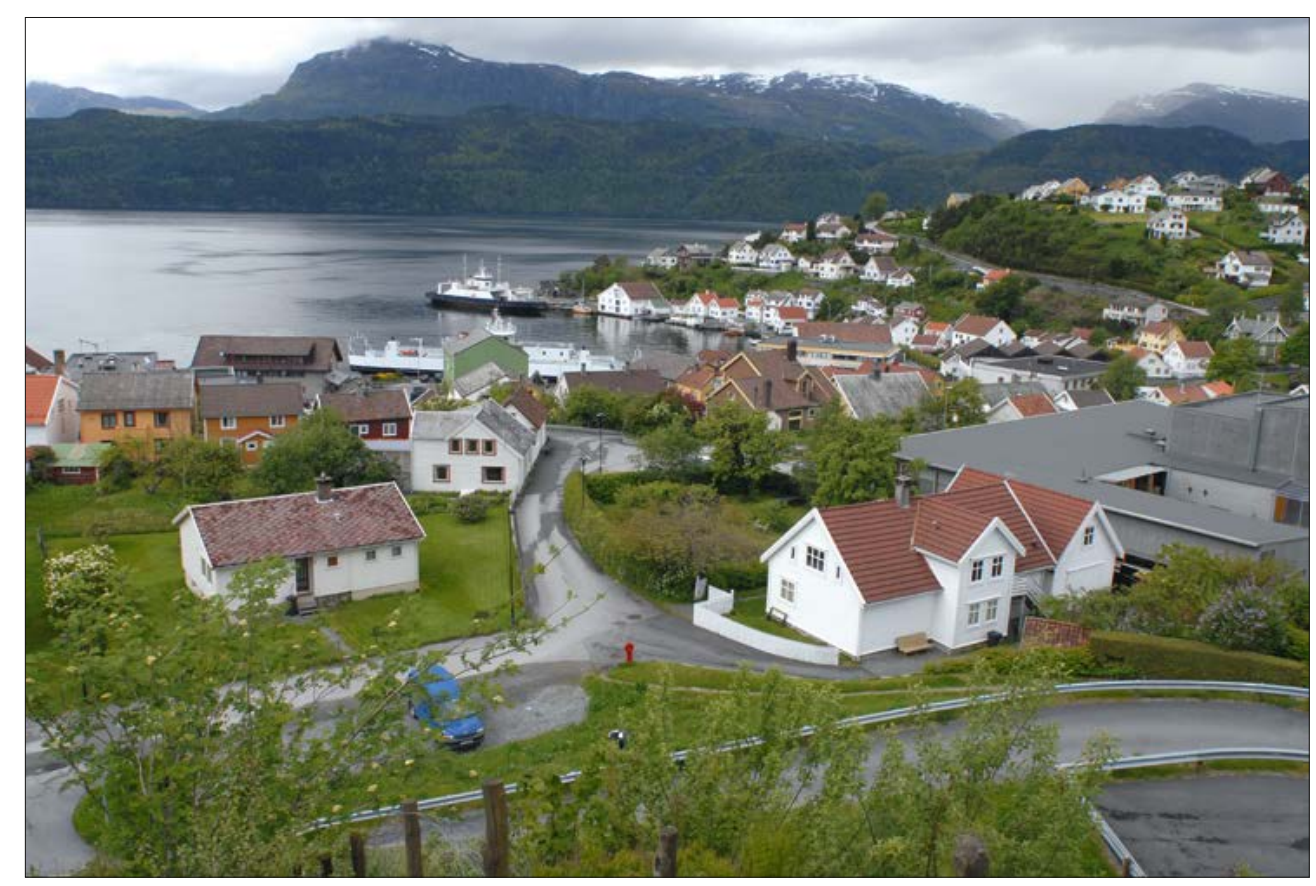

Vurdering av kyrkjestaden: Kyrkjestaden på Jelsa ligg sentralt til i bygda, nær hovudfartsåra - fjorden - og langt frå eitt einskilt gardstun. Staden ligg også sentralt i skipreida, særleg for den sør- og sørvestlege delen av denne. Kommunikasjonane til og frå kyrkjestaden er gode. Det skal ha vore førkristne gravminne inne på kyrkjegarden, noko som indikerer kultstadskontinuitet.

\section{Sand kyrkje}

Gard: Sand, gnr. 103, bnr. 185, Suldal kommune.

Nemnd første gong: Sanskirkiu, DN II 35, 1295. Nemnt første gong som sokn i 1283 (parochia de Sand), DN II, 21.
Nedlagd eller flytta: Den gamle kyrkja vart riven i 1852. Ny kyrkje vart bygd om lag 25 m sørvest for der den gamle stod. Den gamle kyrkja stod på den vestlege delen av «Kyrkjehauen» (Foldøy 1981:232), der kyrkjegarden framleis er.

Namn på kyrkjestad: Sand. Gards- og bygdenamn, og seinare soknenamn.

Lokalisering og topografi: I mellomalderen låg kyrkja på Sand oppå ein morenehaug, om lag 25 m høgare enn den noverande kyrkja (Fig. 9). I vest er Sandsfjorden og Ropeidhalvøya. I søraust og sør er Suldalslågen som her renn ut i Sandsfjorden. 


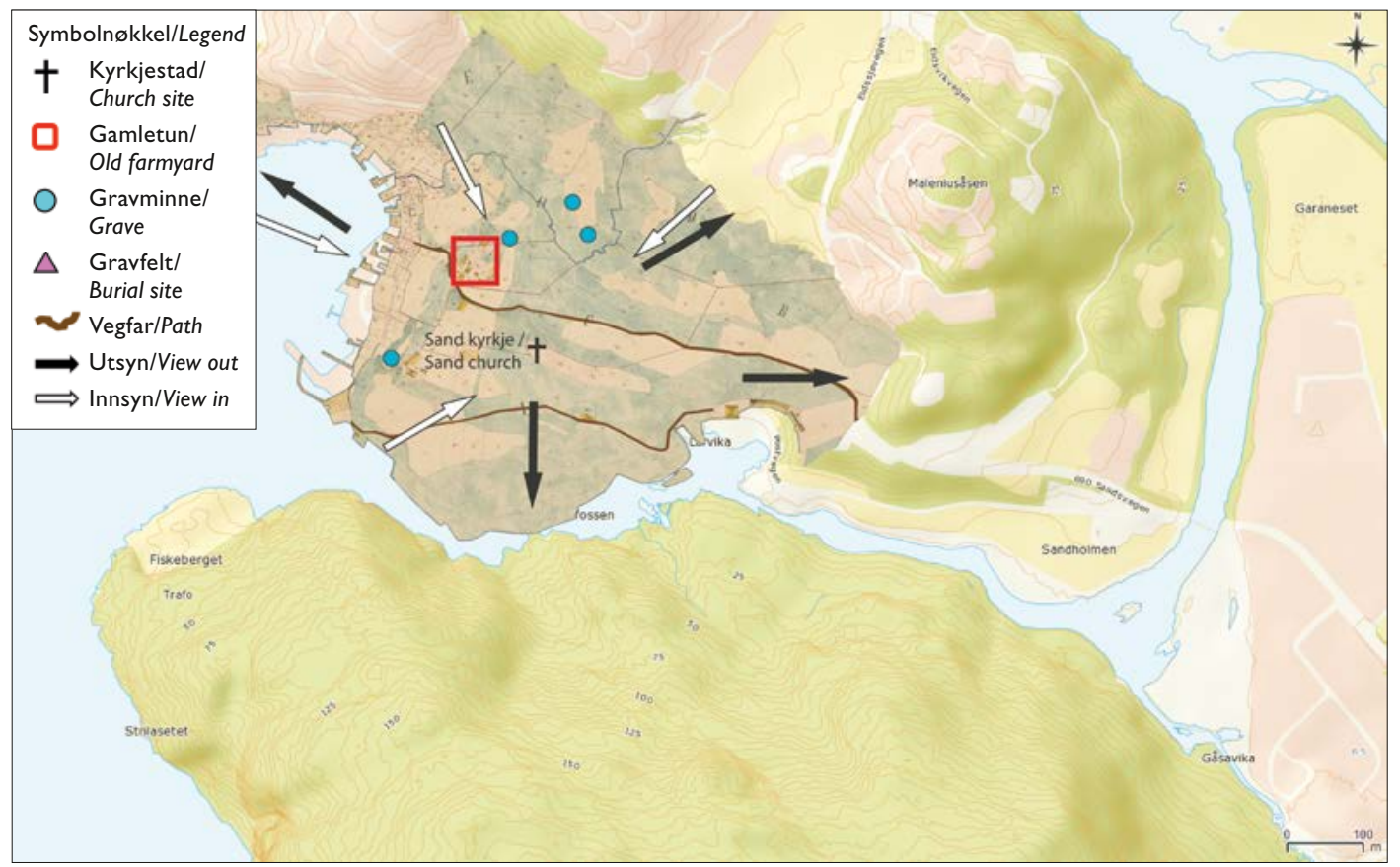

Fig. II. Oversiktskart over Sand kyrkjestad. Kart: S. Magnell.

Fig. II. Map of Sand church site. Map by: S. Magnell.
Omkringliggande kulturminne: Det er i dag ikkje registrert nokon gravhaugar eller gravrøyser i tilknyting til den gamle kyrkjestaden, men tre flatmarksgraver daterte til jernalder og yngre jernalder finst i sørvest og nordaust.

Kyrkjestaden $i$ forhold til veg, elv/vatn, tun og tingplass: Det gamle tunet på Sandsgarden skal ha lege like nedanfor den gamle kyrkjestaden (Fig. 9 og 10). Ifølge utskiftingskartet gjekk den gamle bygdevegen $20 \mathrm{~m}$ nordanfor kyrkjestaden. Etter gammalt var Sand også tingplass (Drange 2000:9).

Henvending: Kyrkja henvender seg særleg mot Sandsfjorden og Ropeid i vest og nordvest (Fig. 11). Mellomalderkyrkja har hatt ei særs spesiell plassering i det ho har vore reist på eit markant høgdedrag, sett i forhold til resten av landskapet, om lag 20 m over resten av den næraste busetnaden. Dette gjev både godt innsyn til og vidt utsyn frå kyrkjestaden. Likevel er ikkje kyrkja plassert så synleg med omsyn til fjernverknad, noko som har samanheng med det dalliknande landskapet og at Sand ligg i ei vik.

Vurdering av kyrkjestaden: Den gamle kyrkjestaden låg i tilknyting til tunet på garden, på ein stad av særs monumental karakter. Det er registrert tre flatmarksgraver på garden, to daterte til vikingtid, noko som tyder på kultstadskontinuitet. Kyrkjestaden ligg nær fjorden, men er likevel ikkje knytt til denne.

\section{Suldal skipreide}

I Suldal skipreide er det ein kyrkjestad frå mellomalderen, Vinjar, som ligg etter måten sentralt til i skipreida.
Skipreida (Súladals skipreiða) er nemnd første gong i brev i 1402 (DN XVI, 44).

\section{Vinjar kyrkje}

Gard: Vinjar (Prestegarden), gnr. 27, bnr. 1, Suldal kommune.

Nemnd første gong: kirkjan á Vinju i Súladal, DN IV, 764, 1407. Nemnd første gong som sokn i 1319 (Viniusokn i Suladale, DN IV, 129).

Nedlagd eller flytta: Ingen opplysningar som tilseier det.

Namn på kyrkjestad: Vinjar. Gardsnamn og seinare soknenamn og er usamansett pl. av -vin som tyder naturleg eng (Olsen 1926:178, 182, Sandnes \& Stemshaug 1997: 495). Magnus Olsen peika på at desse usamansette vingardane ofte ligg sentralt i bygdene (Olsen 1926:195).

Lokalisering og topografi: Kyrkjestaden er plassert i vestre delen av ein morenerygg, på ein plass der Suldalen breier seg ut som ei vid og open slette (Fig. 12 og 13). Kyrkja ligg ikkje høgare enn resten av busetnaden på sletta. Om lag $200 \mathrm{~m}$ nord for kyrkja reiser Vinjanuten (ca. 1100 moh.) seg og dannar ein slags vegg. I aust, mot gardane Hoftun og Fisketjørn, er der store flate marker og eit ope landskap. Omlag 1,3 km aust for kyrkjestaden ligg osen der Suldalsvatnet renn ut i Suldalslågen.

Omkringliggande kulturminne: Like ved kyrkjestaden skal det ha stått to gravhaugar frå jernalderen utan nærare dateringar (Lillehammer 1982). Tidlegare skal det ha lege ein god del fleire gravhaugar av ulik form og storleik på sletta der prestegarden ligg (Kraft 1845:438). Det er kan hende frå desse haugane mange av gravfunna 
Fig. 12. Vinjar kyrkjestad og landskapet rundt sett frå Tingabrekk mot sør. Foto: A. Skeiseid. Fig. 12. Vinjar church site and the surrounding landscape seen from Tingabrekk. Towards south. Photo: A. Skeiseid.

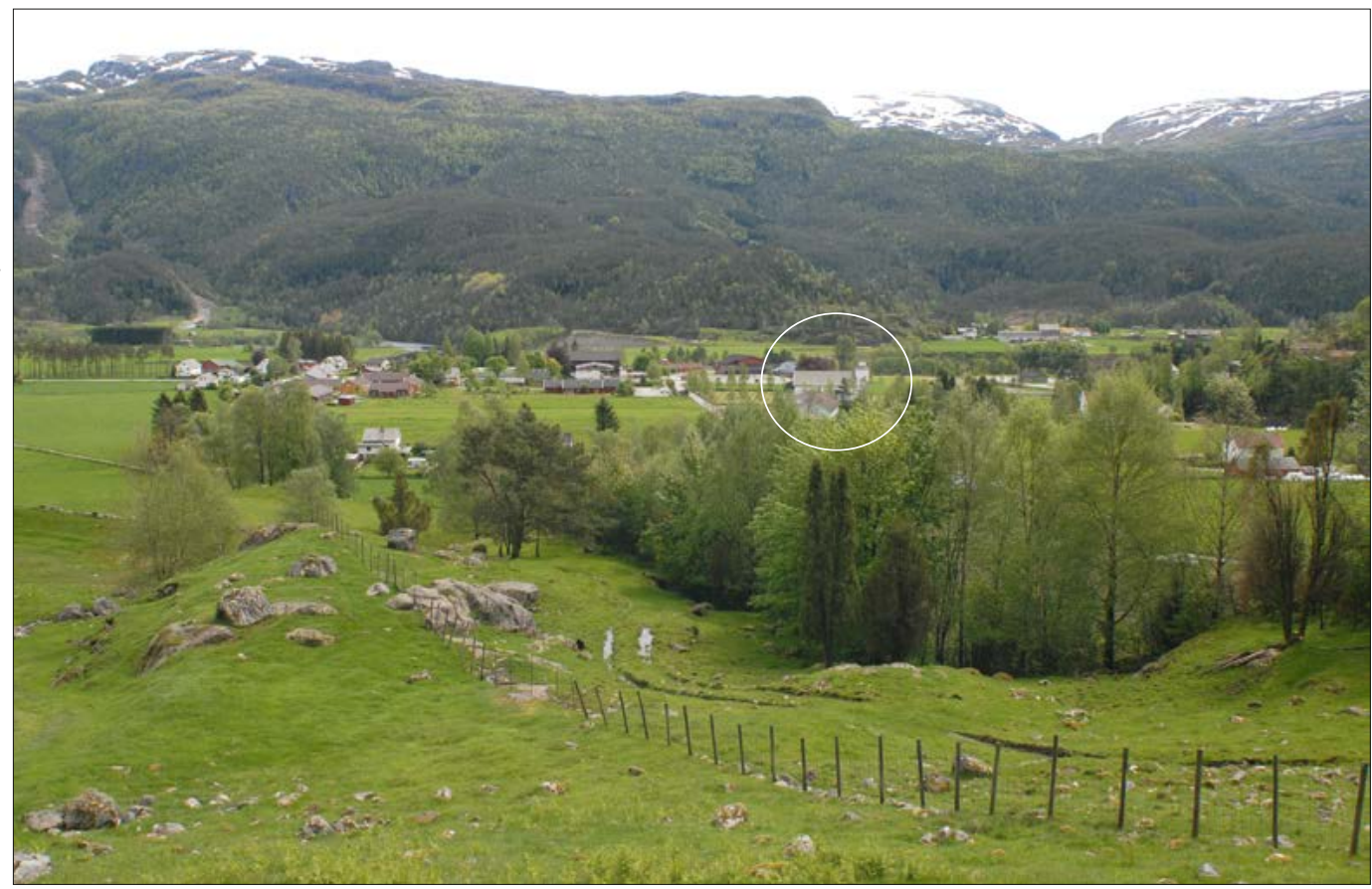

Fig. 13. Oversiktskart over Vinjar kyrkjestad. Kart: S. Magnell. Fig. 13. Map of Vinjar church site. Map by: $S$. Magnell.

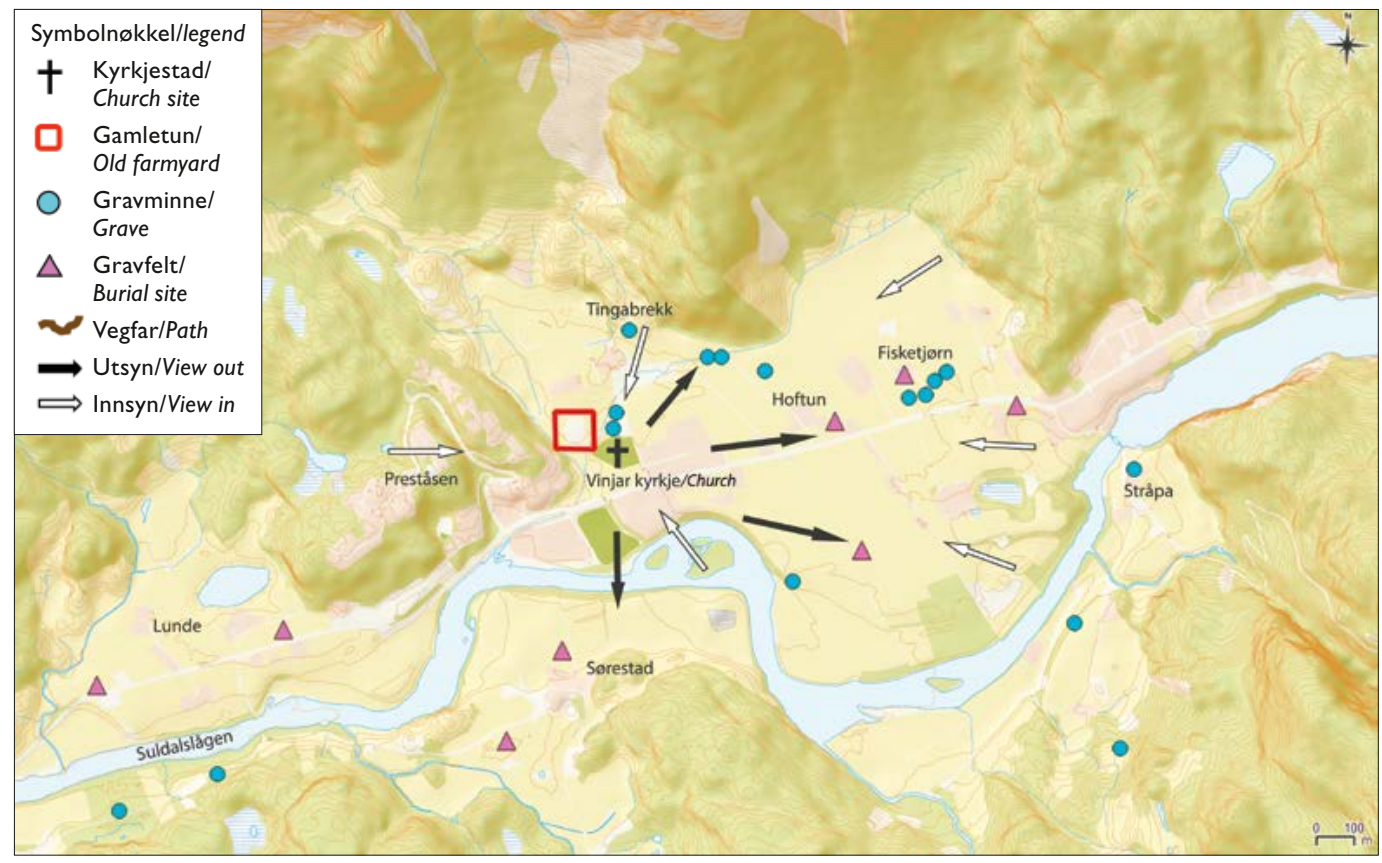

daterte til yngre jernalder kjem. ${ }^{4}$ På nabogarden Hoftun (gnr. 29) er der fleire gravhaugar, somme daterte til eldre jernalder. Innanfor ein distanse mellom 500 m-1 $\mathrm{km}$ aust for kyrkjestaden har der vore eit større gravfelt med gravrøyser og gravhaugar (Lund 1938). Også på Fisketjørn (gnr. 30) er der fleire gravhaugar frå jernalderen. På Sørestad (gnr. 26) i sør er det i underkant av 20 gravhaugar og på Stråpa (gnr. 31) i søraust ligg det fleire gravhaugar, to daterte til vikingtid. Alle har, utanom dei på Stråpa, visuell kontakt med kyrkjestaden på Vinjar.

Kyrkjestaden $i$ forhold til veg, elv/vatn, tun og tingplass: $300 \mathrm{~m}$ sør for kyrkjestaden renn Suldalslågen, og vegen gjennom bygda går omlag $50 \mathrm{~m}$ sør frå kyrkja. Suldalsvatnet ligg $1,3 \mathrm{~km}$ søraust for kyrkjestaden. Tunet på Vinjar (Prestegarden) ligg ca. 75 m nordvest for kyrkjestaden, med eit tydeleg dalsøkk i mellom. Rett ved kyrkjegardsmuren i aust går gardsvegen som fører opp til Hoftun og Vinjar. Om lag 160 m nord for kyrkjestaden, på grannegarden Hoftun, ligg Tingabrekk der tradisjonen seier at gudehovet og tingstaden låg i heidensk tid.

Henvending: Det er godt innsyn til kyrkjestaden frå aust og sør og relativt bra frå vest. Utsyn frå kyrkjestaden mot vest er noko hindra av ein ås, Preståsen. Elles er utsynet godt over det flate landskapet. 
Vurdering av kyrkjestaden: Kyrkjestaden er ikkje plassert i tilknyting til noko tun, då det ligg eit markert dalsøkk mellom. Kyrkja ligg sentralt til i bygda nær ein tingstad og forholdsvis sentralt i skipreida. Folk som budde lengst inne i dalen, kan ha kome seg til kyrkja med båt på Suldalsvatnet. Kyrkja ligg nær det som truleg har vore den gamle bygdevegen (i dag Rv13). Nokre gravminne har lege tett ved kyrkjegardsmuren, noko som indikerer kultstadskontinuitet. Det har vore mange gravminne på garden.

\section{Samla vurdering}

På dei tre undersøkte kyrkjestadene på midtre Jæren synest kyrkjene å ha vore plasserte i tilknyting til tunet på garden. Også i indre Ryfylke ligg ei kyrkje, Sand, i tilknyting til gamletunet på garden, medan dei to andre - Jelsa og Vinjar - har ei meir sentral plassering, i bygda og i skipreida.

Ingen av kyrkjestadene på midtre Jæren er plasserte i tilknyting til ein tingplass. Når det gjeld tingplassar, peikar kyrkjestadene Sand og Vinjar i indre Ryfylke seg ut. På Vinjar skal tingplassen ha lege berre $150 \mathrm{~m}$ frå kyrkja.

Når det gjeld kommunikasjonar og tilgjenge, er det til dels store ulikskapar mellom dei ytre stroka og delar av dei indre stroka. Jelsa ligg nært knytt til fjorden. Også Sand ligg til fjorden, men kyrkjestaden er trekt noko tilbake, oppå ein markert haug. Dei undersøkte stadene på midtre Jæren er i det store og heile i liten grad knytte til elv, vatn eller hav. Her har truleg ferdsla til lands vore primær.

Alle dei undersøkte stadene ligg på gardar som har gravminne frå jernalder innanfor sine grenser, men det er stor variasjon i avstanden mellom gravminne og kyrkjestad. Biletet er heller ikkje eintydig, verken i indre eller ytre strok. På Bore og Vinjar har det stått gravhaugar inntil kyrkjegardsmuren, på utsida. På Jelsa har det stått ein gravhaug inne på sjølve kyrkjegarden. Bore, Sand og Vinjar kyrkjestader ligg på gardar som har gravminne daterte til yngre jernalder.

Kyrkjestadene i ytre strók - Time, Klepp, Bore - og Sand i indre strók ligg på stader med ein monumental karakter, på høgder eller høgdedrag i landskapet. Dei viser seg å vere svært synlege i landskapet. På Jæren vender dei monumentale stadene seg til eit stort område rundt, medan kyrkjestaden på Sand i indre Ryfylke har eit meir avgrensa henvendingsområde grunna den lokale topografien, med fjell ikring. Også kyrkjestaden på Jelsa er svært synleg plassert ved sjøen utan å ha den same monumentale verknaden. Vinjar kyrkje ligg godt synleg på ei flat slette, men ikkje monumentalt.

Alle kyrkjestadene, utanom på Jelsa, ligg på gardar med same namn som kyrkjestaden. Fleire av gardane med kyrkje har gjeve namn til einingar utanom garden: til bygda og til soknet, Jelsa og Kleppe også til skipreidene.

\section{Gardar med kyrkje og deira økonomiske status}

Kostnadene ved å bygge kyrkje og halde ho ved like må ha vore etter måten store, jamvel om somme av kyrkjene var små bygningar i tre i den første fasen, slik som stavkyrkjene Høre og Haltdalen (Anker 1996:112, 268). Kompleksiteten i arbeid, innsats og kostnad kjem tydeleg fram i artikkelen «Bygningstekniske og arkeologiske bemerkninger om trekirker i Norge i vikingtid og middelalder» (Jensenius 2010). Men i tillegg til sjølve bygget trongst det tomt til kyrkje og kyrkjegard, og presten skulle ha lovfest underhald (G 15). Dei som i Gulatingslova blir kalla «einskildmenn» må difor ha sete på gardar som hadde sterk økonomisk bereevne, eller som også har hatt annan eigedom.

Ved å undersøke økonomisk status for dei gardane der det vart reist kyrkje og jamføre dei med andre gardar i sine respektive skipreider, kan vi sjå om dei skilde seg ut i storleik frå andre gardar. Her må ein ha i mente at gardane kan ha omfatta underliggjande gods tidlegare, og at dei yngre kjeldene ikkje alltid fangar inn slike tilhøve.

Resultata vil bli haldne saman med funna vedrørande plassering, i eit fors $ø$ k på å finne ut om det var einskildbønder eller eit bygdefellesskap som var initiativtakarar då dei første kyrkjene vart bygde, og som slik fremja kristendommen. Har situasjonen vore den same eller ein annan på midtre Jæren og i indre Ryfylke med omsyn til kven som har gått i brodden for kyrkjereising?

Som nemnt finst det ikkje samtidsopplysningar frå mellomalderen om gardane si økonomiske bereevne, og vi må difor nærme oss dette spørsmålet retrospektivt ut frå yngre kjelder, i første rekkje skattematrikkelen frå 1647. Her vart norske gardar takserte etter kor stor landskyld dei hadde - ut frå kor stor årleg leige ein leiglending skulle betale til jordeigaren. Sidan landskylda stod i eit visst høve til storleiken på garden målt etter produktivitet, vart landskylda etter kvart «ein hendig målestav for garden i forhold til andre gardar» (Marthinsen [1980] 1991:11).

Ein føresetnad for å kunne bruke matrikkelen retrospektivt er at det har vore stor grad av stabilitet i ein gard si produksjonsevne gjennom hundreåra. At det faktisk er ein slik stabilitet og kontinuitet, er noko forskarar peikar på som overraskande vanleg (Bjørkvik 1995:62ff., Lunden 2002:359).

Det er likevel fleire problem knytte til bruken av ei langt yngre kjelde som grunnlag for tidlegare tiders økonomiske og eigedomsmessige forhold, til dømes 
at eigedomsforhold mange stader kan ha endra seg. Opplysningane må difor nyttast med varsemd og så langt råd er bli haldne saman med eldre bevarte kjelder, inklusive stadnamn.

Skattematrikkelen 1647 er likevel den eldste kjelda som kan gje eit samla bilete av gardar si økonomiske bereevne. Det er det relative storleiksforholdet gardane imellom som vil bli vektlagt, slik at vi kan sjå om gardar som har kyrkje skil seg ut samanlikna med andre gardar i skipreida. "Relativ verdi" tek utgangspunkt i gjennomsnittsverdien for alle gardane i ei skipreide og indikerer kor mange gonger større eller mindre landskyldverdien på ein gard er samanlikna med gjennomsnittsgarden.

Tabellane til høgre viser først landskyld og relativ verdi for dei gardane som har kyrkje og som er oppførte i matrikkelen 1647. Vidare viser dei landskyld og relativ verdi for dei fem største gardane i dei undersøkte skipreidene. Prestegardar, andre embetsmannsgardar og gardar som adelen åtte rundt midten av 1600-talet, var unnatekne landskyld og skatt og er ikkje nemnde i skattematrikkelen, jf.* i Tabell 2 (Gjermundsen [1980]1991:34, Try [1980]1991:38). Eg har difor henta opplysningar om desse gardane si landskyld i den seinare skattematrikkelen frå 1723, der slike opplysningar finst.

Når det gjeld kva for vareslag landskylda vart betalt i, har dette variert frå område til område. I indre Ryfylke var det smør som var det rådande vareslaget, men somme gardar betalte også i tjøre, huder og «tag» (never). På midtre Jæren var korn den vanlegaste betalingsvara. Nedanfor er all landskyld rekna om til laupar smør, slik at det er mogleg å samanlikne dei ulike gardane. ${ }^{5}$

\section{Haug og Klepp skipreider}

I Haug skipreide var det ein kyrkjestad - Time - og i 1647 fører skattematrikkelen opp 38 gardar. Samla landskyld i skipreida er på 68,22 laupar smør, som gjev eit gjennomsnitt på 1,79 laupar smør.

I Klepp skipreide var det to kyrkjestader - Klepp og Bore - og i 1647 fører skattematrikkelen opp 37 gardar i skipreida med ei samla landskyld på 91,5 laupar smør. Gjennomsnittsverdien for gardane var 2,47 laupar smør.

Tabell 1 syner at gardane i Haug skipreide var temmeleg jamstore i tidleg nytid, den største ikkje meir enn vél to og ein halv gonger større enn gjennomsnittsgarden. Garden Øvra Time, garden med kyrkjestad, var blant dei største gardane i skipreida, men ikkje meir enn 1,7 gonger større enn gjennomsnittsgarden. Ingen av gardane skil seg klart ut som storgardar; den største, Njå, er 2,7 gonger så stor som gjennomsnittsgarden. Desse tilhøva er likevel ikkje heilt representative for tilhøva fleire hundreår tidlegare.
Tabell I. Oversyn over kyrkjestader (i kursiv) og dei fem største gardane i Haug og Klepp skipreider, målt etter landskylda i skattematrikkelen 1647.

Table I. Overview of church sites (in italics) and the five largest farms in the Haug and Klepp "skipreider", measured according to the 1647 landed property tax register.

\begin{tabular}{|c|l|c|c|}
\hline $\begin{array}{l}\text { Skipreide/ } \\
\text { "Skipreide" }\end{array}$ & $\begin{array}{l}\text { Gard og } \\
\text { gardsnummer/ } \\
\text { Farm and farm } \\
\text { unit number }\end{array}$ & $\begin{array}{l}\text { Landskyld - i } \\
\text { laupar smør/ } \\
\text { Landed property } \\
\text { rent in "laupar" } \\
\text { butter (I laup: } \\
\text { cal5 kilos) }\end{array}$ & $\begin{array}{l}\text { Relativ verdi/ } \\
\text { Relative value }\end{array}$ \\
\hline Haug & $\begin{array}{l}\text { Øvra Time, gnr. I7 } \\
\text { (iTime k.) }\end{array}$ & 3 & I,7 \\
\hline Haug & Njå, gnr. 24 & 4,8 & 2,7 \\
\hline Haug & Frøyland, gnr. 28 & 4,3 & 2,4 \\
\hline Haug & $\begin{array}{l}\text { Tu, gnr. I7 } \\
\text { (i Klepp k.) }\end{array}$ & 4,3 & 2,4 \\
\hline Haug & Store Oma, gnr. 13 & 4 & 2,2 \\
\hline Haug & Herikstad, gnr. II & 3 & 1,7 \\
\hline Klepp & Kleppe, gnr. I & 4,5 & I,8 \\
\hline Klepp & $\begin{array}{l}\text { Vestre Bore, } \\
\text { gnr. 44 }\end{array}$ & 3 & I,2 \\
\hline Klepp & Sele, gnr. 5I & 7,5 & 3 \\
\hline Klepp & $\begin{array}{l}\text { Skjæveland, gnr. 52 } \\
\text { (i Sandnes k.) }\end{array}$ & 6,5 & 2,6 \\
\hline klepp & Gruda, gnr. 3 & 6 & 2,4 \\
\hline Klepp & Anda, gnr. 14 & 5 & 2 \\
\hline Klepp & Friestad, gnr. 24 & 4,3 & I,7 \\
\hline & & & \\
\hline
\end{tabular}

Tabell 2. Oversyn over kyrkjestader (i kursiv) og dei fem største gardane i Jelsa og Suldal skipreider, målt etter landskylda i skattematrikkelen 1647.

Table 2. Overview of church sites (in italics) and the five largest farms in Jelsa and Suldal "skipreider", measured according to the 1647 landed property tax register.

\begin{tabular}{|c|l|c|c|}
\hline $\begin{array}{l}\text { Skipreide/ } \\
\text { "Skipreide" }\end{array}$ & $\begin{array}{l}\text { Gard og } \\
\text { gardsnummer/ } \\
\text { Farm and farm } \\
\text { unit number }\end{array}$ & $\begin{array}{l}\text { Landskyld - i } \\
\text { laupar smør/Landed } \\
\text { property rent in } \\
\text { "laupar" butter } \\
\text { (I laup: ca I5 kilos) }\end{array}$ & $\begin{array}{l}\text { Relativ } \\
\text { verdi/ } \\
\text { Relative } \\
\text { value }\end{array}$ \\
\hline Jelsa & $\begin{array}{l}\text { Prestegarden, } \\
\text { gnr. I39* }\end{array}$ & - \\
\hline Jelsa & Sand, gnr. I03 & 4 & 2,4 \\
\hline Jelsa & Hebnes, gnr. II2 & 8,8 & 5,3 \\
\hline Jelsa & Fuglastein, gnr. I45 & 4,7 & 2,8 \\
\hline Jelsa & Hanakam, gnr. 96 & 4,3 & 2,6 \\
\hline Jelsa & Helland, gnr. 94 & 3,8 & 2,3 \\
\hline Jelsa & Kjølvik, gnr. I I6 & 3,5 & 2,1 \\
\hline Suldal & Vinjar, gnr. 27* & $(2)$ & $($ I,3) \\
\hline Suldal & Lunde, gnr. 25 & 5,4 & 3,5 \\
\hline Suldal & Veka, gnr. 34 & 4,8 & 3, I \\
\hline Suldal & Gautun, gnr. 59 & 4,5 & 2,9 \\
\hline Suldal & Bakka, gnr. 4I & 4 & 2,6 \\
\hline Suldal & Tjøstheim, gnr. 24 & 4 & \\
\hline
\end{tabular}


På 1600-talet var Time-garden skilt ut i ein Øvra og ein Nera Time-gard. Slike utskiljingar skjedde som regel i tidleg mellomalder eller i høgmellomalderen (Øye 2002:247ff.). Slik sett er det sannsynleg at garden kan ha vore større då kyrkja vart reist. I tidleg mellomalder sat bonden på Time-garden likevel ikkje på ein gard med eit omframt solid økonomisk fundament, med mindre garden hadde inntekter frå andre gardar.

Når det gjeld Klepp skipreide kan det sjå ut som om vi her har å gjere med eit område som er tydeleg rikare enn Haug skipreide. Vi skal samstundes vere klar over at verdifastsetjinga kunne variere skipreidene imellom, og det er difor også her den relative verdien innanfor skipreida er mest interessant.

Tabell 1 viser også for Klepp skipreide at dei største gardane ikkje skilde seg markant ut; dei kunne vere vél to og ein halv gonger større enn gjennomsnittsgarden. Den eine garden med kyrkje, Kleppe, var blant dei fem største i skipreida i 1647, men ikkje meir enn knappe det doble av gjennomsnittsgarden. Om Klepp kyrkje skriv historikaren Birger Lindanger (1990:49) at det var slekta på Kleppe som på 1100-talet fekk reist kyrkje på garden.

Den andre garden med kyrkje, Vestre Bore, var ikkje særleg mykje større enn ein gjennomsnittsgard i skipreida. Til liks med Time er også Bore ein gard som er blitt delt i løpet av mellomalderen, i Vestre og Austre Bore. Dette tyder på at Bore-garden under eitt må ha vore monaleg større og med ei større økonomisk bereevne i tidleg mellomalder enn det skattematrikkelen 1647 gir inntrykk av. Om Bore skriv Lindanger (1990:73) at det var «[S]tormennene på Orre, Reve og Bore [som] sytte (...) for at Bore og Orre fekk eigne kyrkjer og blei skilde ut som sokn».

\section{Jelsa og Suldal skipreider}

I Jelsa skipreide var det to kyrkjestader, Jelsa og Sand. Kyrkja på Jelsa ligg ifølgje lokalhistorikaren Ola Foldøy (1967:554) på Sandane, eit lite underbruk under Prestegarden. Skattematrikkelen 1647 gjev opp 95 gardar i skipreida. Den samla landskylda var på 159 laupar smør, med ei gjennomsnittleg landskyld på 1,67 laupar.

I Suldal skipreide var der éin kyrkjestad. Denne låg på garden Vinjar, eit stykke frå det som i 1647 og i dag er prestegardstun. I følgje skattematrikkelen 1647 var der 68 gardar i denne skipreida. Samla landskyld i skipreida var på 105,7 laupar smør, eit gjennomsnitt på gardsnivå på 1,55 laupar.

Tabell 2 viser eit noko annleis mønster enn i Haug og Klepp skipreider, med større skilnad gardane imellom. Hebnes er den klårt største, meir enn fem gonger så stor som gjennomsnittsgarden. Også Sand var blant dei største gardane i skipreida av dei som er førde opp i skattematrikkelen; nesten to og ein halv gong så stor som gjennomsnittsgarden. Sandskyrkja åtte det meste av dagens matrikkelgard Sand, i det minste frå slutten på 1200-talet (Drange 2007, pers. meddeling).

Foldøy nemner at kongen åtte prestegarden på Jelsa* i tidleg nytid og at garden var benefisert presten på Jelsa (Foldøy 1967:554). Dei to gardane, Prestegarden (Berg) og Sandane, er difor ikkje nemnde i skattematrikkelen 1647, jf.* i Tabell 2. Garden Jelsa har gjeve namn til skipreide, kyrkjestad og sokn. Tabellen syner også at det fanst gardar med solid økonomisk bereevne i Suldal skipreide. Kyrkje- og prestegarden Vinjar er ikkje ført opp i skattematrikkelen 1647, men landskylda på 2 laupar smør, oppgjeven i matrikkelen i 1723, syner at garden ikkje er blant dei fem største i skipreida.

\section{Samla vurdering}

Med utgangspunkt i skattematrikkelen 1647 har eg sett kva for økonomisk status gardane med kyrkje har hatt i høve til dei største gardane i sine respektive skipreider. Det syner seg at ingen av dei aller største gardane i dei ulike skipreidene har kyrkje på grunnen sin, verken i undersøkingsområda i indre Ryfylke eller på midtre Jæren. Det ser med andre ord ut til at kyrkjer ikkje er blitt reiste på markante storgardar, men likevel på gardar med ei godt over gjennomsnittleg økonomisk bereevne.

I den første kristentida var det vanleg at kyrkjelyden kjøpte kyrkjelege tenester av ein lokal prest (Helle 2001:205). Det var difor viktig for ei kyrkje å ha dåpsog gravrett, som del av inntektsgrunnlaget sitt (Helle 2001:204). Hovudkyrkjene, fjordungskyrkjene og truleg heradskyrkjene hadde slik rett, men ikkje alle dei tidlege gardskyrkjene. Det var biskopen som hadde hand om dåps- og gravretten.

\section{Kven bygde kyrkjene?}

Eg finn det rimeleg at gardskyrkjene i mitt materiale kan ha hatt dåps- og gravrett tidleg, kanskje frå dei vart bygde, av tre grunnar. For det fyrste vart dei alle soknekyrkjer seinare, noko som kan vere ein indikasjon på at kyrkjene - om dei var bygde før sokneskipnaden - tidlegare hadde dekt behovet for kyrkjelege tenester i sine respektive bygdelag. For det andre har det i Rogaland vore vanskeleg å lokalisere hovud- og fjordungskyrkjene - kyrkjer som hadde dåps- og gravrett (Helle 2001:203). For det tredje har ein ikkje funne spor etter nedlagde heradskyrkjer i dei undersøkte områda, kyrkjer som eventuelt kunne ha hatt dåps- og gravretten i bygdelaget.

Som nemnt identifiserer Gulatingslova to grupper kyrkjebyggjarar: på eine sida «dei menn som eig kyrkja» 
og på andre sida «einskildmenn (...), (...) lendmann (...) eller bonde eller kven det er som byggjer kyrkje», i resten av G 12 referert til som «bonden». Kyrkjene bygde av denne siste gruppa vert gjerne kalla høgendeskyrkjer, eller gardskyrkjer. Kjenneteikn på ei gardskyrkje er i første rekkje at ho er plassert nær eit gardstun, slik at ho ikkje nødvendigvis ligg sentralt i bygda (Skre 1984:11), og at ho ligg på ein gard som ville ha økonomisk bereevne til å reise og halde oppe ei kyrkje. At kyrkjestaden har namn etter garden han ligg på kan også peike i retning av at ein har å gjere med ei gardskyrkje.

Kyrkjer bygde av «dei menn som eig kyrkja» - av bygdefellesskapet - er kjenneteikna ved å ha ei relativt sentral plassering i bygda og gjerne vere lettare tilgjengelege enn gardskyrkjene. Dei bér gjerne namnet på skipreida eller bygda dei ligg i. Det er også døme på at kyrkjer som vart reiste i fellesskap låg på gardar der eigaren tydelegvis har avstått grunn (Berg 2005). Kyrkjer kunne også vere bygde på allmenningsgrunn og ved gamle sentra (Birkenes 2004).

Historikaren Halvard Bjørkvik (1995:76) teiknar opp eit bilete av at stormenn på øyane i ytre Ryfylke og på Stavangerhalvøya har vore nøkkelpersonar i organiseringa av kyrkjereising i desse områda. Finn vi det same mønstret eller er det eit anna på midtre Jæren og i indre Ryfylke?

I indre Ryfylke er kyrkjestadene Sand og Vinjar plasserte på eller nær garden som hyste tingstaden. Sand var tingstad frå gammalt av, men lokaliseringa er ikkje kjend (Drange 2000:9). Vinjar er nabogarden til Hoftun med tingstaden Tingabrekk. For mange ville vegen til kyrkja vere den same som vegen til tingstaden, berre nokre hundre meter kortare. Dei nye kultstadene vart såleis i ein viss grad skipa ved plassar som vi kan gå ut frå har vore samlingsplassar før kristninga, i form av kyrkjereising, skaut fart. På midtre Jæren ligg ingen av kyrkjene nær ein tingstad.

\section{Stormenn bygger kyrkje}

Fire av kyrkjestadene som er blitt undersøkte i denne framstillinga - Time, Klepp, Bore og Sand - er alle plasserte i tilknyting til gamletun. Time og Klepp kyrkjer har ikkje midtpunktplassering i bygda; den gamle Sandskyrkja låg berre om lag $150 \mathrm{~m}$ frå fjorden, men samstundes 38 meter over havet, ei stigning på heile 25 prosent.

Dette kan tyde på at dei fire kyrkjene opphaveleg vart bygde som gardskyrkjer. Alle kyrkjene vart seinare soknekyrkjer. Sannsynlegvis på grunn av nedgang i folketalet etter Svartedauden vart Bore annekskyrkje under Klepp og Sand under Jelsa kyrkje.
Eitt moment synest likevel å kunne tale mot at desse fire kyrkjene var gardskyrkjer: spørsmålet om desse gardane har hatt økonomisk bereevne for kyrkjebygging. Såleis hadde Vestre Bore i 1647 ei landskyld som var noko i overkant av gjennomsnitttsgarden i denne skipreida, med relativ verdi 1,2. Men som nemnt reflekterer ikkje skattematrikkelen av 1647 direkte tilhøva på 1000 - og 1100-talet. Vestre Bore og Austre Bore er oppførte som to separate gardar i skattematrikkelen, men busetnadshistorisk dreier det seg her om éin gard med to tun (Rønneseth 2001:141). Namna tyder på utskiljing i tidleg mellomalder eller høgmellomalderen (Øye 2002: $247 \mathrm{ff}$.), og i alle høve kan delte namnegardar ha utgjort ei naturleg samarbeidseining ved organiseringa av kyrkjebygging også etter at dei var delte (Skre 1984:30). Samla var dei to Bore-gardane om lag dobbelt så store som gjennomsnittsgarden i skipreida. Birger Lindanger (1990:51) skriv at det budde ei stormannsætt på Boregarden, som var mellom dei største i bygda. Kyrkja på Bore var plassert i tilknyting til gamletunet på garden, på «Kyrkjeågeren».

Eit liknande forhold, med delt gard, ser vi på Timegarden, som i 1647 var delt i Øvra Time og Nera Time. Samanslegne ville dei to gardane ha utgjort éi eining vél dobbelt så stor som gjennomsnittsgarden i skipreida. Ein eldre veg går ved og rundt kyrkjestaden, men denne har inga sentral plassering i høve til busetnaden i skipreida.

Den gamle kyrkjestaden på Kleppe var også plassert nær gamletunet på garden. For bygdefolket kan tilgjenge ha vore noko avgrensa, då Kleppe ligg på ei høgd i landskapet. Det var også gardsnamnet Kleppe som gav namn til skipreida, då det var naturleg at skipreida «fekk namn etter sætegarden til denne mektigaste mannen på midtre Jæren» (Lindanger 1990:47). Samstundes kan dette tyde på at garden var sentral i bygda alt tidleg då skipreida vart organisert.

I Tabell 2 ser vi at Sandsgarden var ein etter måten stor gard i si skipreide, med relativ verdi 2,4 , nesten to og ein halv gong så stor som gjennomsnittsgarden i skipreida. Det synest dermed klårt at Sand kan ha vore ein gard stor nok til å bere kostnadene med å reise gardskyrkje. På den andre sida har Sand vore tingstad, og garden ligg sentralt i bygda, noko som kan tyde på ei kyrkje bygd i fellesskap. Men den nære tilknytinga til gamletunet på garden og kyrkja si manglande direkte tilknyting til fjorden indikerer likevel at vi her har å gjere med ei gardskyrkje. Garden kan også ha omfatta eigedomar andre stader, men dette er vanskeleg å dokumentere ut frå dei tilgjengelege kjeldene. Om det har vore ei gardskyrkje, er det rimeleg å tenkje seg at det sat ein større jordeigar her då kyrkja opphaveleg vart reist. 


\section{Bygdefolket reiser kyrkje}

Jelsa kyrkje har inga spesiell tilknyting til noko tun. Ho er sentralt plassert i skipreida si med tanke på ferdsle til sjøs og er nær knytt til fjorden. Kyrkjestaden ligg innan Prestegarden (Berg) sitt gardsvald. Det gamle gardsnamnet Berg, eit usamansett naturnamn, kan tyde på ein gammal gard, kan hende frå jernalder. Det gjer det mindre sannsynleg at det ligg føre ei seinare utskiljing av prestegarden med kyrkjestad, frå grannegarden Jelsa. Mest sannsynleg er det difor at kyrkjestaden har namn etter skipreida Jelsa, ikkje direkte etter garden Jelsa. Desse forholda kan peike mot at Jelsa kyrkje opphaveleg vart reist som eit fellestiltak av bygdefolket.

Noverande Suldal kyrkje ${ }^{6}$ bar tidlegare namnet Vinjar kyrkje. Som det går fram av Tabell 2 syner matrikkelen frå 1723 at Vinjar var prestegard og dermed ikkje skyldsett i 1647. Landskylda låg ikkje mykje over landskylda for gjennomsnittsgarden i skipreida. Kyrkjestaden ligg ikkje meir enn 100-150 m frå det som truleg er gamletunet, noverande prestegardstun, men verkar likevel ikkje å vere knytt til dette då det er eit dalsøkk imellom. Kyrkjestaden ligg sentralt i bygda nær bygdevegen og like ved vegen til garden Hoftun, der den gamle tingstaden og kanskje også ein forhistorisk kultstad har vore lokaliserte (Hoftun 1981:42). I høve til gardstunet på Vinjar ligg kyrkja 100-150 m nærare Suldalsosen og dermed til ferdsla på Suldalsvatnet.

Namnet Vinjar kan tyde på ein eldre gard; at det kan ha skjedd ei seinare utskiljing av prestegarden frå ein av grannegardane, Lunde eller Hoftun, er mindre sannsynleg då kyrkjestaden i så fall opphaveleg ville ha fått namn etter ein av desse gardane. Det er såleis mest sannsynleg, at Vinjar kyrkje frå fyrst vart reist som eit fellestiltak. Jan Brendalsmo (1994:110) tenkjer seg at fellesbygde kyrkjer med bygdenamn opphavleg kan ha hatt gardsnamn. Etter kvart har den namnegjevinga som folk utanfor bygda har gjeve kyrkja blitt den vanlege.

Av dei undersøkte kyrkjestadene ser det ut til at fire av kyrkjene - Time, Klepp og Bore på midtre Jæren og Sand i indre Ryfylke - opphaveleg er reiste som gardskyrkjer, medan to - Jelsa og Vinjar - tenderer mot å vere reiste i fellesskap av eit bygdelag. Geografisk er tendensen med kyrkjer knytte til ein gard tydelegast i Klepp og Haug skipreider, i det som her utgjer ytre strók.

\section{Kva tid vart kyrkjene bygde?}

Er det mogleg å komme nærare eit svar på om kva tid kyrkjestadene vart skipa? Eitt haldepunkt er datering av gravminne som kan nyttast som ei terminus post quem-datering for skipinga: Kyrkja kan tidlegast ha blitt reist etter det yngste daterte heidenske gravminnet. Analysar av
${ }^{14} \mathrm{C}$-prøver frå utgravingar på kyrkjegarden og dendrokronologiske undersøkingar av trerestar frå ei opphaveleg kyrkje kan også gje ei nokolunde dateringsramme i dei tilfella der slike moglegheiter ligg føre. Så langt har dette berre vore mogleg på nokre få kyrkjestader, mellom anna Veøy i Romsdal (Solli 1996).

Når det gjeld kyrkjestadene i mine undersøkingsområde, manglar empirisk grunnlag for å kunne føreslå tidspunkt for skiping av desse seks stadene - kan hende med unnatak av Bore (sjå nedanfor). Dateringane for gravminne frå yngre jernalder er desse så generelle at dei ikkje eingong kan gje eit omtrentleg tidspunkt for kva tid den heidenske gravskikken tok slutt i undersøkingsområda. Det einaste det er mogleg å slå fast er ei terminus ante quem-datering av kyrkjestadene ut frå mellomalderbrev - kva tid dei seinast kan ha vore skipa. Årstala i Tabell 3 syner kva tid prest, kyrkje eller sokn første gong er nemnde, og såleis kva tid kyrkjene seinast er blitt reiste:

På generelt grunnlag vil det likevel vere mogleg å gjennomføre ein diskusjon kring spørsmålet om tidleg eller sein skiping, i tidsrommet 1030 til 1330, med utgangspunkt i føresegner i kristenretten i G.

Bak vedtaket om kyrkjebygging som vart gjort på Mostratinget ein gong i 1020-åra, stod både konge og bønder. Mange av bøndene som møtte, kan ha vore kjende med kristen tru og kristen praksis, andre kan ha opplevt at dei ikkje hadde anna val enn å bøye seg for kongemakta. I alle fall kan det vere tvilsamt om bøndene kollektivt i dei einskilde bygdene raskt tok i ferde med å reise kyrkjer den første tida etter vedtaket på tinget, sjølv om lova opna opp for at dei kunne vere kyrkjebyggarar, som den eine av to grupperingar (G 12). Ein ting som kunne tale for å byggje kyrkje var at dei då ville få lett tilgjenge til kyrkjelege tenester. Det dei på andre sida ville måtte bere var byggjekostnader, kjøp av kyrkjevigsle frå bispen, utskiljing av jord til opphaldsgard for kyrkja, vedlikehald av kyrkja, kjøp av kyrkjelege tenester hjå presten (Adam av Bremen/Koht 1950:79). Mange bønder kan ha sett på dette som eit dårleg balansert byte; det var ikkje sikkert dei oppfatta nytteverdien av kyrkjereising den første tida (Andersen 1977: 326). Dessutan kan den gamle trua framleis ha stått sterkt blant bøndene.

For å komme i gong med kristning gjennom kyrkjebygging måtte difor kongen, kan vi tenkje oss, finne andre lokale alliansepartnarar. Den andre gruppa kyrkjebyggarar peikt på i lova er som nemnt «einskildmenn (...) anten lendmann eller bonde (...) eller kven det er som reiser kyrkja» - heretter referert til som «stormann».

I eit lite kommentert avsnitt i Gulatingslova (G 12, siste avsnitt) vert det fastlagt kva som skulle skje om ein «stormann» let kyrkja si rotne. Han måtte bygge ho opp 
Tabell 3: Oversyn over når kyrkjestadene er nemnde, ved prest, kyrkje eller sokn, første gong i Diplomatarium Norvegicum terminus ante quem-dateringar.

Table 3. Overview of when the church sites are mentioned, by priest, church or parish for the first time in Diplomatarium Norvegicum terminus ante quem.

\begin{tabular}{|c|r|r|r|r|}
\hline $\begin{array}{c}\text { Kyrkjestad/ } \\
\text { Church site }\end{array}$ & Prest/Priest & $\begin{array}{r}\text { Kyrkje/ } \\
\text { Church }\end{array}$ & $\begin{array}{l}\text { Sokn/ } \\
\text { Parish }\end{array}$ & $\begin{array}{l}\text { Terminus } \\
\text { ante quem }\end{array}$ \\
\hline Time & 1329 & 1395 & - & 1329 \\
\hline Klepp & - & ca. 1280 & - & ca. 1280 \\
\hline Bore & - & - & 1322 & 1322 \\
\hline Jelsa & - & ca. 1280 & - & ca. 1280 \\
\hline Sand & - & 1295 & 1283 & 1283 \\
\hline Vinjar & - & 1407 & 1319 & 1319 \\
\hline
\end{tabular}

att innan tre år, elles ville kongen eige jorda ho stod på. Kongen måtte få bygd ny kyrkje innan eitt år, elles skulle stormannen ha jorda si att og bygge kyrkje innan eitt år. Om ikkje dette vart gjort, skulle kongen ha jorda for alltid. Knut Helle (2001:201) peiker på at reglane «syner (...) at kongen stilte seg bak bygging og vedlikehald av kyrkjer og hadde interesse i dette», men er usikker på om slike pedantiske reglar kan ha blitt strengt praktiserte. Eg vél å tolke desse som gjennomtenkte reglar - dei vart ikkje tekne ut i Magnusteksten ${ }^{7}$ - lovfeste for å gjere det mogleg for konge og stormenn å gje kvarandre så god tid at dei kunne unngå brot med kvarandre. Opptil fem års utsetjing kunne stormannen få før han miste jorda som kyrkja sto på for godt. Jamvel om han i mellomtida måtte betale bøter på seks merker til biskopen, fekk han etter det eg kan sjå ei mindre streng handsaming enn dei bøndene som kollektivt hadde bygt kyrkje og forsømt vedlikehaldet. Det ser ut til at det å reise kyrkje skulle innebere minst mogleg risiko for stormannen. Når lova heller ikkje inneheldt andre føresegner som truga eigedom eller ære, kan det ikkje ha vore vanskeleg for stormenn som hadde teke ved den kristne trua å gå i allianse med kongen og bli lokale pådrivarar i kristninga av landet gjennom kyrkjebygging.

I vikingtidas og mellomalderens samfunn var samkvem mykje basert på utveksling av gåver - yting og motyting - og også kongen kunne skaffe seg tilslutning gjennom gåver og velgjerningar (Helle 1991:31, Bagge [1998] 2005:158). Spørsmålet er om kongen hadde gåver å gje for å knyta til seg stormenn som alliansepartnarar og få dei til å ta kostnadene med å byggje kyrkjer, leggje naudsynt jord til kyrkja - noko kanonisk rett kravde (Smedberg 1973:139) - og halde ho ved like.

Kongen hadde slike gåver å tilby stormenn som ønskte å fremje kristendommen lokalt ved å reise kyrkjer. Stormannen ville få kongens venskap (Skre 1995:172) og kongens vern; han ville få høve til å syne makt og eigen rikdom ved at kyrkjestaden og eit monument - kyrkjebygget - låg på hans gard; han fekk halde oppe ein tradisjon med å ha graver på eigen gard (Birkenes 2004).

Like eins fekk han behalde råderetten over jord som han la til kyrkja - han miste ikkje retten om han forsømde vedlikehaldet - og over inntektene frå jorda (Smedberg 1973:93-94). Han kunne få rett til å tilsetje prest, om det så var ein av sine nærskylde. Etter at tienda vart innførd i første helvta av 1100-talet, kunne stormannen ha styring med delar av denne (Skre 1995:178). Smedberg (1973: 99) meiner at det kan ha vore ein «lönande affär» å ha kyrkje oppførd på eigen gard.

Kongen på si side må ha fått motytingar. Viktigast må vi tru det har vore at stormenn si kyrkjebygging gav kongen høve til effektivt å fremje kristendommen i lokalsamfunna. Gjennom det Kåre Lunden (2004:26) kallar dei rike, mektige og prestisjeberande sitt «ideologiske hegemoni», kan det ha blitt sett i gong ein prosess der også lågare samfunnssjikt byrja å ta ved den nye trua. Og kongane fekk eit nettverk av lojale alliansepartnarar omkring i landet. Slik vart kongen si makt underbygd og faren for opprør mindre (Skre 1995:172).

Utover på 1100-talet kan bøndene ha fått større interesse for sjølve å reise kyrkjer i fellesskap. For det første er det rimeleg at kristendommen har blitt sterkare rotfest blant folk etter lang tids kristen påverknad. For det andre vart tiendeordninga innførd. Helvta av tienda skulle gå til opphald for prest og vedlikehald av kyrkje, og bøndene ville kunne få betre styring med denne delen av tienda ved reising av eiga heradskyrkje, etter kvart soknekyrkje. For det tredje spreidde det seg frå tidleg på 1100-talet ein ny byggeteknikk for stavkonstruksjonar, slik at vedlikehaldet av kyrkjene vart enklare og mindre kostbart: stolpeholsteknikken vart erstatta av botnramme på svillar og seinare steinmur (Nordhagen 2003:92).

For stormenn sin del kan det utover på 1100-talet ha blitt mindre attraktivt å bygge kyrkjer. I andre halvdelen av hundreåret nådde den gregorianske reformrørsla Noreg. Canones Nidrosienses, truleg frå 1160-åra, viser at kyrkja prøvde å få kontroll over innsetjinga av prestar og herredøme over jordegods som stormennene hadde lagt ut til kyrkja (Skre 1995:177). Skre (1995:179) meiner kyrkjeeigarane kan ha sett på dette som ein "vederstyggelighet". Dersom kyrkja skulle vinne fram med krava sine, risikerte stormenn å miste makt og delar av styringsretten over eigedom som dei tidlegare hadde lagt ut til kyrkja.

Vi må også kunne tenke oss at det i fleire og fleire område etter kvart var blitt bygt tilstrekkeleg med kyrkjer i høve til folketalet. Ei kyrkje bygd av ein stormann ville då kunne bli nekta dåps- og gravrett av biskopen, 
eller ho vart ikkje soknekyrkje og fekk dermed ikkje inntekter av tienda.

Den moglege utviklingstendensen som eg her har skissert, med potensielt auka kyrkjebygging initiert av bøndene kollektivt og redusert bygging av gardskyrkjer, kan i tilfelle ha teke til før midten av 1100-talet og halde fram ut hundreåret, då behovet for kyrkjer i all hovudsak må ha vore dekt (Bagge [1998] 2005:84). Dette vil likevel ikkje seie at det ikkje vart bygt gardskyrkjer så seint som på 1200-talet - til dømes finn historikaren Kjetil Haaland ([1998] 2001:36ff.) at gardskyrkjer i stein er blitt bygde i denne perioden, eller at fellesbygde kyrkjer kan ha blitt reiste alt på 1000-talet.

På generelt grunnlag har eg argumentert for at gardskyrkjer, som Klepp, Time, Bore og Sand kyrkjer i tendens kan ha blitt bygde noko tidlegare enn fellesbygde kyrkjer. Jan Brendalsmo (1994:107) vurderer sitt materiale frå Vestfold slik at dei fleste tidlege mellomalderkyrkjene vart bygde av og for samfunnseliten på deira gardar. På andre sida har Dagfinn Skre (1984:80) vurdert Ringebu kyrkje i Sør-Gudbrandsdalen som eit tidleg fellesbyggeri frå 1000-talet. Biletet er samansett, og vi kan heller ikkje sjå bort frå variasjonar landsdelane imellom.

Dateringa for Bore kyrkje kan truleg snevrast noko inn. På Bore kyrkjegard finst det fleire runesteinar med namn på døde personar, men ingen årstal for når dei døydde. Runesteinane kan tyde på at kyrkja er frå 1200talet (Lindanger 1990:51). Ein døypefont i kleberstein frå denne kyrkja er ut frå ornamenta datert til 1140-åra (Haaland 2001:29, 165, Solhaug 2001:31ff.).

Diskusjonen ovanfor viser at det er uråd å tidfeste skiping av kyrkjestader i mine undersøkingsområde, anna enn at gardskyrkjene i tendens kan ha blitt oppførte tidlegare enn dei fellesbygde kyrkjene.

\section{Kva omsyn er tekne i val og skiping av kyrkjestad?}

Tabell 4 oppsummerer tidlegare observasjonar kring kyrkjestadene si plassering i landskapet, og er eit utgangspunkt for diskusjonen. Det må understrekast at det ikkje let seg gjere å få fram alle nyansar i ein slik tabell.

\section{Omsyn til gamle rituelle stader - brot eller kontinuitet} Spørsmålet om kontinuitet eller brot ved skipinga av nye kultstader er som tidlegare nemnt vurdert ut frå kriteriet visuell kontakt mellom kyrkjestad og heidenske graver på same garden. Alle dei seks undersøkte stadene ligg på gardar med gravminne frå jernalderen. Gardane Bore, Sand og Vinjar har gravminne som kan daterast til yngre jernalder. Alle kyrkjestadene har visuell kontakt med førkristne gravminne. Kyrkjestadene på Vinjar, Jelsa og Bore ligg tett ved slike gravminne.
Gravminna på Time, Klepp og Sand ligg på stader utan like tydeleg tilknyting til kyrkjestaden. Desse tre gardane har grannegardar med monaleg fleire gravminne. Kor nøyaktig dette reflekterer eldre forhold er uråd å vite då gravminne kan ha blitt fjerna i nyare tid, slik vi ut frå tidlegare skildringar (jf. Kraft 1845) og Tor Helliesens kart veit er tilfelle både i indre Ryfylke og på midtre Jæren.

Legg vi observerte data til grunn, finn vi sterk grad av kultstadkontinuitet på Vinjar, Jelsa og Bore, svakare på Sand, Time og Klepp. Ved alle kyrkjene finn vi ein tendens som peiker mot kultstadkontinuitet.

Det kan vere grunn til å sjå nærare på Vinjar, ein av stadene markerte med nærliggjande graver. Garden grensar opp mot Hoftun som var gammal tingstad, gard med mange gravminne og kan hende stad for heidensk kultutøving. Når Vinjar vart vald som kyrkjestad for Suldal, ikkje Hoftun, vil det vere mogleg å tolke dette slik at folk i bygda kan ha vendt seg bort frå den gamle religionen representert ved Hoftun, men ikkje bort frå bandet med forfedrane representert ved gravene på Vinjar.

\section{Omsyn til monumentalitet?}

Det har blitt hevda at monumentet gjer staden meir synleg (Bradley [1993] 1996:106). I tidleg norsk mellomalder, med små trekyrkjer som kanskje ikkje skilde seg så mykje ut frå andre bygningar, kan det vel tenkjast eit motsett fall: at staden har gjort monumentet meir synleg. Finn vi eit slikt forhold på dei undersøkte kyrkjestadene - at staden peiker ut monumentet?

Fire av kyrkjene, Sand, Bore, Klepp og Time kyrkjer er plasserte på stader med monumental karakter. Desse fire stadene skil seg klårt ut i landskapet ved at dei utgjer markante høgdedrag i sine nærområde og henvender seg til eit vidt omland.

I 1850-åra vart kyrkja på Sand flytta frå den gamle staden og ned dit ho står i dag. Ein grunn for flyttinga var at vedlikehaldet vart for krevjande slik kyrkja stod, på ei svært verutsett høgd. I valet mellom monumentalitet og rimeleg vedlikehald er det såleis truleg at monumentalitet har vore viktigast då den første kyrkja vart reist på Sand.

Kyrkjestaden på Jelsa ligg ikkje på eit høgdedrag, men nede ved sjøen. Likevel verkar staden monumental for den som reiser sjøvegen, i det han er godt synleg og har ein vid innsynsvinkel. At kyrkjestaden på Vinjar ikkje er lagd til ein monumental stad kan forklarast ut frå topografien: ei eventuell monumental plassering ville ha komme i konflikt med omsyn som sentralitet og tilgjenge. I høve til sletta ho ligg på, har kyrkja ei maksimalt synleg plassering. 
Tabell 4. Oversikt over kyrkjestadene si plassering i landskapet.

Teiknforklaring: ++ = høg grad, + = mindre grad av, - = ikkje ei slik kopling.

Table 4. Summary of the placement of the church sites in the landscape.

Explanation: ++ = high degree of, $+=$ lower degree of, - = not such a connection.

\begin{tabular}{|c|c|c|c|c|c|c|}
\hline $\begin{array}{l}\text { Kyrkjestad/ } \\
\text { Church site }\end{array}$ & $\begin{array}{l}\text { Plassering } \\
\text { nær gardstun/ } \\
\text { Proximity to } \\
\text { farmyard }\end{array}$ & $\begin{array}{l}\text { Nærleik til førkristne } \\
\text { gravminne/Proximity } \\
\text { to pre-Christian burial } \\
\text { mounds/burial sites }\end{array}$ & $\begin{array}{l}\text { Plassering på/ved } \\
\text { gammal samlingsplass/ } \\
\text { Proximity to older } \\
\text { assembly site }\end{array}$ & $\begin{array}{l}\text { Nærleik til } \\
\text { fjord eller vatn/ } \\
\text { Proximity to fjord } \\
\text { or lake }\end{array}$ & $\begin{array}{l}\text { Nærleik til større } \\
\text { veg/Proximity to } \\
\text { lane/road }\end{array}$ & $\begin{array}{l}\text { Monumentalitet/ } \\
\text { Monumentality }\end{array}$ \\
\hline Time & ++ & + & - & + & + & ++ \\
\hline Kleppe & ++ & + & - & - & $?$ & ++ \\
\hline Bore & ++ & ++ & - & + & ++ & ++ \\
\hline Jelsa & - & ++ & + & ++ & + & + \\
\hline Sand & ++ & + & ++ & + & ++ & ++ \\
\hline Vinjar & + & ++ & ++ & + & ++ & + \\
\hline
\end{tabular}

Dei fire kyrkjene som er identifiserte som gardskyrkjer - Klepp, Bore, Time og Sand - står alle på det høgaste punktet på garden dersom kravet om nærleik til tunet samstundes skal kunne bli oppfylt. Sidan kyrkja også gjerne skulle markere stormannen si tilknyting til kongen, høvde det seg at ho vart gitt ei dominerande plassering i landskapet. Ei monumental plassering var også nødvendig for at kyrkja skulle kunne forkynne Guds makt og samstundes vere ei forlenging av sendaren, eigaren som kommuniserer bodskapen om eiga makt.

Dei to kyrkjene eg har vurdert som fellestiltak, Jelsa og Vinjar, kommuniserer tilgjenge med si sentralplassering nær ferdsleårer. Men også desse kyrkjestadene er godt synlege i landskapet.

\section{Makt og maktkontinuitet}

I dei områda som her er undersøkte, har vi sett at stormenn på gardar med økonomisk bereevne for kyrkjebygging har reist kyrkjer - her kalla gardskyrkjer. Forutan vurderingar knytte til religiøs overtyding, er det nærliggjande å tenke seg at maktaspektet ved kyrkjereising har vore viktig når ein stormann tok på seg å byggje kyrkje: Ville det å byggje kyrkje kunne sikre han og etterkomarane hans den makta som ætta hans tidlegare hadde hatt? Ville resultatet av avgjerda vere fortsatt, eller jamvel, auka makt?

Kongemakta i Noreg voks på 1000-talet og eit stykke utover på 1100-talet. Venskap med kongen ville då vere viktig for ein stormann for å sikre eiga makt. Ein slik venskap kunne vinnast ved å bygge kyrkje (Skre 1995:172). Dersom kyrkjeeige i tillegg var økonomisk lønsamt, slik Smedberg (1973) hevdar, ville kyrkjereising også kunne byggje opp under garden sin økonomiske status og på den måten sikre ein vidare maktposisjon.

Kyrkjebyggaren fekk vidare kontroll over gravene til forfedrane (Birkenes 2004), og gjennom lovpålegget om gravlegging i vigd jord (G 23) fekk stormannen også kontroll med andre slekter sine graver som no vart liggjande på hans gard. På same tid måtte bygdefolket, inklusive andre stormenn, komme til hans gard for å få utført lovpålagde kyrkjelege tenester, i hans kyrkje og av hans prest.

Vi har sett at gardskyrkjer til vanleg vart bygde $\mathrm{i}$ nærleiken av tunet. For kyrkjelyden kunne plasseringa av kyrkja nær tunet kommunisere stormannen sin vilje til makt gjennom alliansen med kongemakta.

\section{Kyrkjestader i ytre og indre Rogaland - ei samanlikning}

I denne artikkelen har eg teke utgangspunkt i spørsmålet om likskapar og skilnader mellom kyrkjestadene i to område i Rogaland, med tanke på å identifisere tendensar i kristningsprosessen i dei to områda: Kven bygde kyrkje, kva tid og kvifor er kyrkjene plasserte slik dei er?

På alle seks kyrkjestadene finn vi kultstadskontinuitet gjennom visuell kontakt ut frå kyrkjene til gamle gravminne. Bore og Vinjar kyrkjer har gravminne nær inntil kyrkjegardsmuren; Jelsa skal endåtil ha hatt slike inne på kyrkjegarden. Kleppe, Time og Sand har gravminne på garden, men her låg gravene lenger borte. Det er vanskeleg å sjå eit mønster, men to av kyrkjene i indre strok - samanfallande med dei som synest å vera fellestiltak har gravminne med nærleik til kyrkja.

Det finst ikkje spor etter nedlagde kyrkjestader i nokon av skipreidene der mine undersøkingar er lokaliserte. Ei skipreide i ytre strok og ei i indre har to kyrkjestader, den andre skipreida i kvart område har berre ein. Talet på kyrkjer i skipreidene kan ha samanheng med folketalet. Alle kyrkjene i dei to undersøkingsområda vart etter kvart soknekyrkjer - fram til 1300-talet då Bore og Sand kyrkjer vart annekskyrkjer under høvesvis Klepp kyrkje og Jelsa kyrkje. Dette siste forholdet kan ha samband med ein nedgang i folketalet etter 
Svartedauden og kan vere ein indikasjon på at dei vart bygde som gardskyrkjer.

Kyrkjestaden på Sand i indre Ryfylke oppviser dei same trekka som er karakteristiske for kyrkjestadene med gardskyrkjer på midtre Jæren, først og fremst det at han er knytt til gamletunet og samstundes plassert høgast mogleg i landskapet.

Skilnadene mellom midtre Jæren og indre Ryfylke er meir markante enn likskapane. For det første synest alle kyrkjene i det eg kallar ytre strok å vere gardskyrkjer, noko som kan tyde på at det har vore andre aktørar her og kan hende også ei noko tidlegare kristning enn det vi finn i indre strok. Kyrkjestader, dei første markørane for den nye religionen i indre strok, vart knapt skipa før utover på 1000-talet, etter vedtaket på Mostratinget.

Ingen av kyrkjene på midtre Jæren ligg nær gamle samlingsplassar, ein indikasjon på at dei er gardskyrkjer. Det synest å ha vore mindre vekt på å legge kyrkjene nær gamle samlingsstader her enn i indre Ryfylke. Den større graden av nærleik til ferdslevegar i indre Ryfylke kan ha samanheng med større vektlegging av tilgjenge når bygdefolket, slik eg har tolka data, gjekk saman om å byggje kyrkje.

Medan alle kyrkjene i dei kystnære skipreidene er blitt vurderte som gardskyrkjer, er to av tre kyrkjer i skipreidene i Jelsa og Suldal vurderte som å vere reiste av bygdefolket i fellesskap. Ettersom eg tidlegare på generelt grunnlag har argumentert for ein tendens til at kollektivt bygde kyrkjer kan ha blitt reiste på eit noko seinare tidspunkt enn gardskyrkjene, skulle det vere rimeleg at vi finn kyrkjer som fellestiltak i indre Ryfylke: Dette vert predikert av hypotesen om spreiing av kristendom frå kyst til innland. Det som synest å vere i strid med hypotesen, er at rekna frå kysten er rekkjefølgja denne: fellestiltak (Jelsa) - gardskyrkje (Sand) - fellestiltak (Vinjar), ikkje som vi kunne ha venta gardskyrkje - fellestiltak - fellestiltak.

Fleire gardar i ytre delen av Jelsa skipreide hadde økonomisk bereevne til å reise kyrkje (jf. Tabell 2). Svakt ressursgrunnlag kan såleis ikkje vere forklaringa på at det ikkje synest å ha vore bygt gardskyrkje i området.

Ein forklaringsmåte vil då kunne vere at påverknaden frå kristne idear kom tidlegare til Sand og den indre delen enn til den ytre delen av skipreida. I så fall kan dette best forklarast ved at Sand, som tidlegare nemnt, var eit knutepunkt for ferdsle: til lands mot Suldal, Røldal og Telemark, til sjøs mot Imsland, Sandeid og Bergen, og framfor alt mot Stavanger. På andre sida var Jelsa-området geografisk nærare impulsane frå dei kystnære områda enn Sand.

Ein alternativ forklaringsmåte kan vere for svakt befolkningsgrunnlag i den tidlege fasen av kristninga til å bere meir enn ei kyrkje i skipreida. Dei som budde i ytre strok av Jelsa skipreide i tidleg kristen tid kan ha fått kyrkjelege tenester av ambulerande prestar, og kjøpt gravferdstenester ved kyrkjer som hadde gravrett.

På andre sida må vi ikkje binde oss opp i den førestellinga at gardskyrkjer alltid vart bygde tidlegare enn kollektivt reiste kyrkjer, sjølv om det som nemnt finst forsking som kan tyde på ein slik tendens (Brendalsmo 1994:107). Jelsa kyrkje kan såleis vere bygd samtidig med eller endåtil før Sand kyrkje. Det verkar ikkje urimeleg at dei to delane av skipreida, det meir kystnære Jelsa og knutepunktet Sand, kan ha fătt si første kyrkje - blitt kristna - på nokolunde same tid. Vinjar kyrkje sin sannsynlege status som bygdekyrkje kan tyde på samanheng med seinare kristen påverknad i Suldal skipreide enn i Jelsa skipreide, men også dette er usikkert.

\section{Oppsummering}

Sogene kan gi inntrykk av at Noreg vart kristna ved sverdslag, ved slaget på Stiklestad og ved heilagkåringa av Olav Haraldsson. I denne artikkelen har eg peikt på andre mekanismar som kan ha vore vel så viktige i kristninga av landet:

1. Lovgjeving, i form av innføring av kristenretten.

2. Økonomiske insentiv som fylgje av ny jurisdiksjon - det ville kunne løne seg for stormenn å byggje kyrkje på sin gard.

3. Effektiv bodskapsbering ved hjelp av monumentalitet og synlegheit gjennom val av stad for bygget som forkynde den nye religionen. Jamsides økonomisk bereevne kan staden sin monumentalitet ha vore eit avgjerande kriterium når den som organiserte reisinga av kyrkjer i tidleg mellomalder, truleg biskopen, peikte på stad for plassering, iallefall for gardskyrkjer.

\section{Summary}

This article investigates the Christianisation of the presentday county of Rogaland, Norway, in light of the establishment of church sites in one coastal and one non-coastal region of the county. The sites under examination include three sites in mid-Jæren and three in non-coastal Ryfylke.

Originally, each location had a wooden church. No remains of the early buildings have been preserved. Hence, it is the locations per se and their designation as church sites that are central to the investigation, which focuses on differences and similarities between the church sites in the regions selected for examination. The aim is to identify patterns in the process of Christianisation: Who erected the churches? At what time were they built? What considerations may have been crucial in determining the location of the churches?

It has been found that Christian influence and Christian ideas were brought to Western Norway from the British 
Isles. Furthermore, it has been argued that conversion to Christianity first took place in coastal areas, before the Christian faith gradually spread inland. My choice of regions for investigation was made accordingly.

The investigation is premised on a pragmatic definition of "Christianisation": an area has been Christianised when a church has been erected. By correlating data from two regions information can be obtained on who were the actors in the conversion process, and inferences can be made concerning their motivation for participating in the implementation of the Christian faith by building churches. The potential significance of differences in property structure and resource base is explored.

The Gulatingslova (Gulating Law) designates propagators to be in charge of church construction: churches were to be built either by local magnates or middle-ranking landowners, or by members of a community as a collaborative effort. Additionally, there are provisions that detail the penalties to be imposed on parishioners who fail to avail themselves of services provided by the church, such as the christening of children or a Christian funeral.

The six churches have been assessed in terms of the surrounding landscape; firstly to address, the issue of whether they had been built at pre-Christian ritual sites or whether the choice of location represented a break with the past; and, secondly, to determine whether a church was a proprietary church built by a landowner or a field church centrally located and built as a collaborative enterprise by the people of the parish. Identification of the initiator may provide clues about the time span for the erection of the church in question.

The section on church law in the Gulatingslova not only decreed the establishment of churches but also the building of "stone walls to fence them off" (G 13), mandated that the dead be brought to the church to be buried in hallowed ground. This raises the issue of continuity versus change in a topographical sense. Cult continuity is defined in spatial terms, so as to make the presence or otherwise of visual contact between pre-Christian burial grounds and church site an important element in the analysis.

On the whole, the differences between central Jæren and non-coastal Ryfylke are more apparent than the similarities. Firstly, all of the churches in what are referred to as coastal areas seem to be proprietary churches, an indication that local landowners may have propagated the new faith at a fairly early stage, whereas church sites may not have been founded in non-coastal areas until the $12^{\text {th }}$ century, long after the adoption of King Olav Haraldson's Church Law into the Gulatingslova in 1023.

Secondly, none of the churches in coastal areas are close to old assembly sites, an indication that little importance was attached to accessibility. The greater degree of proximity to main roads or sea lanes in non-coastal Ryfylke may be attributable to the founders giving considerable attention to accessibility, a feature consistent with community-initiated church-building.

Thirdly, while all the churches in the coastal skipreider (administrative units) have been categorised as private churches, two out of three churches in the Jelsa and Suldal skipreider have been classified as churches built by the villagers collectively. I argue in general terms that such churches likely postdate proprietary churches. If such is the case, we would expect to find community-built field churches in non-coastal Ryfylke, consistent with the hypothesis that Christianity spread inland from coastal areas. What we do find, however, travelling inland from the coast, is a field church (Jelsa) - a proprietary church (Sand) - a field church (Vinjar). The order constitutes a partial contradiction of the hypothesis.

On the basis of the 1647 landed property tax register, I have examined the financial status of the farms with a church on their land relative to the status of the biggest farms in their respective skipreider. It turns out that none of the most prosperous farms in the different skipreider has had a church built on it, neither in central Jæren nor in noncoastal Ryfylke. The churches were built, apparently, not on the biggest farms but on smaller, above medium-sized farms.

Judging by the 1647 landed property tax register, farms on the coastal fringe of Jelsa would have had the financial capacity needed to erect and maintain a church. Thus, the absence of one or more proprietary churches in the area cannot be accounted for in terms of a weak resource base.

Alternatively, the absence could be explained in terms of Christian ideas coming earlier to Sand than to the coastal fringe of the Jelsa skipreide. Sand was a hub in the local network of roads and sea transport: on land towards Suldal, Røldal and Telemark, at sea towards Imsland, Sandeid and Bergen - and first and foremost towards Stavanger. However, the Jelsa mainland was geographically more easily accessible to impulses from coastal areas than Sand.

It could be argued that the Jelsa skipreide was too sparsely populated during the early stages of Christianisation to support more than one church - Sand. The people living in the outer parts of the Jelsa skipreide during the first phase may have been serviced by iterant priests, and may have bought ecclesiastical services such as burials from churches with "gravrett" (the right to perform burials).

However, we might be making a mistake if we stubbornly stick to the assumption that proprietary churches invariably predate churches built collaboratively by villagers, even though some research suggests that this is the case. Thus, the Jelsa field church may have been built simultaneously with or even before Sand Church. It would not be unreasonable to hypothesise that the two parts of the skipreide - Sand, a transport hub, and Jelsa, closer to the coast - were Christianised more or less at the same time.

\section{Referansar}

Adam av Bremen. I Koht, H., 1950. Norrøne bokverk nr. 19. Samlaget, Oslo.

Andersen, P.S. 1977. Samlingen av Norge og kristningen av landet 800-1130. Universitetsforlaget, Oslo.

Andressen, L.T. 1991. Om bruksstørrelse i lys av skyld og skatt. I Fladby, R. \& Winge, H. (red.). Den eldste matrikkelen. En innfallsport til historien. Skattematrikkelen 1647, 2. utgave, s. 44-51. Norsk lokalhistorisk institutt, Oslo.

Anker, P. 1996. Stavkirkene - deres egenart og historie. Cappelens kunstfaglige bibliotek, Oslo. 
http://askeladden.ra.no/sok/ (sist tilgjengeleg 06.04.2016) DN = Diplomatarium Norvegicum - http://www.dokpro. uio.no/dipl_norv/diplom_felt.html (sist tilgjengeleg 23.07.2007)

Bagge, S. [1998] 2005. Mennesket i middelalderens Norge: tanker, tro og holdninger 1000-1300. Aschehoug, Oslo.

Bakka, T. 1997. Stadnamn, vegar og verksemd i Dyraheia. Om stadnamn $i$ heiområdet mellom Setedal/Vest-Telemark og Nordaust-Ryfylke. AmS-Varia 16, Arkeologisk museum i Stavanger.

Berg, L. 2005. Heddal og Røldal. En komparativ analyse av to kirkesteder. Upublisert mastergradsoppgåve i arkeologi, Universitetet i Bergen.

Birkeli, F. 1973. Norske steinkors i tidlig middelalder. Et bidrag til belysning av overgangen fra norrøn religion til kristendom. Universitetsforlaget, Oslo.

Birkenes, L.Ø. 2004. Gard, grav og kyrkje. Ein arkeologisk analyse i Hardangerregionen. Upublisert hovudfagsoppgåve i arkeologi. Universitetet i Bergen.

Bjørkvik, H. 1995. Kva slags samfunn var det som tok imot kristendommen? Den vestnorske samfunnsstrukturen omkring år 1000. I Lidén, H.-E. (red.). Møtet mellom hedendom og kristendom i Norge, s. 58-79. Universitetsforlaget, Oslo.

Bradley, R. [1993] 1996. An archaeology of natural places. Peatfield, London.

Brendalsmo, A.J. 1994. Nye tider - nye skikker? I Hansen J.I. \& Bjerva, K.G. (red.). Fra hammer til kors. 1000 år med kristendom. Brytningstid i Viken, s. 103-117. Schibsted, Oslo.

Brendalsmo, A.J. 2006. Kirkebygg og kirkebyggere. Byggherrer $i$ Trøndelag ca. 1000-1600. Unipub, Oslo.

Brendalsmo, J. \& Sollund, M.-L. B. 2013. Middelalderske kirker i hedenske gravfelt. Viking, 203-218. Norsk arkeologisk selskap, Oslo.

Drange, E.B. P Ryfylkemuseet (pers. meddeling)

Drange, E.B. 2000. Sand - gardar og folk III. Suldal kommune, Sand.

Fladby, R. \& Gjermundsen, J.O. (red.) 1978. Skattematrikkelen $1647 X$ - Rogaland fylke, Universitetsforlaget, Oslo.

Foldøy, O. 1967. Jelsa: Gards- og attesoga. Suldal kommune, Sand.

Foldøy, O. 1981. Suldal kultursoge: Jelsa II. Suldal kommune, Sand.

Gjermundsen, J.O. 1991. Hvor langt kan vi stole på skattematrikkelen? I Fladby, R. \& Winge, H. (red.). Den eldste matrikkelen. En innfallsport til historien. Skattematrikkelen 1647, 2. utgave, s. 33-37. Norsk lokalhistorisk institutt, Oslo.

Gräslund, A.S. 1992. Kultkontinuitet - myt eller verklighet? Om arkeologins möjligheter att belysa problemet. I Nilsson, B. (red.). Kontinuitet $i$ kult och tro från vikingatid til medeltid, s. 129-151. Projektet Sveriges kristnanade publikationer 1, Uppsala.

Grågås, Stavanger stifts og domkapitels jordebok ca. 1620, Hodne K.O. 1986, Agder historielag, Kristiansand.

$G$ = Gulatingslovi, omsett frå gamalnorsk av Knut Robberstad, 1969, Norrøne bokverk 33, Samlaget, Oslo.

Helle, K. 1991. Tiden fram til 1536. I Danielsen, R., Dyrvik, S., Grønlie, T., Helle, K. \& Hovland, E. (red.). Grunntrekk $i$ norsk historie. Fra vikingtid til våre dager, s. 13-106. Universitetsforlaget, Oslo.

Helle, K. 2001. Gulatinget og Gulatingslova. Skald, Leikanger.
Hoftun, H. 1981. Suldal kultursoge - gamle Suldal. Suldal kommune, Sand.

Hovstad, H. 1981. Hva jordskiftekart kan fortelle. I Fladby, R. \& Andreassen, L. (red.). Våre gamle kart, s. 19-30. Universitetsforlaget, Oslo.

Haaland, K. 2001. Fra Rogalands middelalder. Bygdekirker $i$ stein. Monumenter over fylkets aristokrati. Solum, Stavanger.

Jensenius, J. H. 2010. Bygningstekniske og arkeologiske bemerkninger om trekirker $i$ Norge $i$ vikingtid og middelalder. http://stavkirke.info/wp-content/artikler/ jensenius-CM2010.pdf (sist tilgjengeleg 10.04.2016).

Kraft, J. 1845. Historisk-topographisk haandbog over kongeriget Norge. Fabritius, Christiania.

Lillehammer, A. 1970. Om busetnadshistorie i førhistorisk tid. Ei drøfting av somme kjelder. Magistergradsavhandling i arkeologi, Universitetet i Bergen.

Lillehammer, A. 1982. Innberetning om graving av to mulige gravhaugrester på Suldal prestegard, gnr. 27, bnr. 1. Top. Ark. Arkeologisk museum, UiS.

Lindanger, B. 1990. Klepp. Bygdesoge til 1837. Klepp kommune, Kleppe.

Lund, H.E. 1938. Undersøkelse av tre mindre hauger på Hovtun i Suldal s. og p. Top.Ark. Arkeologisk museum, UiS.

Lunden, K. 2002. Frå svartedauden til 17. mai, 1350-1814, Norges landbrukshistorie II. Samlaget, Oslo.

Lunden, K. 2004. Religionsskiftet - sivilisasjonsframvokster - statsdanning - identitets- endring. To studiar i norsk historie frå ca. år 950 til 1300. I Sigurðsson, J.V., Myking, M. \& Rindal, M. (red.). Religionsskiftet $i$ Norden, s. 13-63. Unipub, Oslo.

Marthinsen, L. 1991. Landskyld og landskyldvarer. I Fladby, R. \& Winge, H. (red.). Den eldste matrikkelen. En innfallsport til historien. Skattematrikkelen 1647, 2. utgave, s. 11-15. Norsk lokalhistorisk institutt, Oslo.

McNicol, J. 1997. Plasseringen av de første kirkene $i$ Norge $i$ forhold til de første kultstedene. En historiografisk studie omfattende tiden etter 1830. KULTs skriftserie nr. 98, Oslo.

Müller, I.H.V. 1991. Fra ættefellesskap til sognefellesskap. Om overgangen fra hedensk til kristen gravskikk. I Steinsland, G., Drobin, U., Pentikäinen, J. \& Meulengracht Sørensen, P. (red.). Nordisk hedendom - et symposium, s. 359-373. Odense universitetsforlag, Odense.

NIyR III = Norske innskrifter med de yngre runer. Tredje bind . VIII. Aust-Agder, IX. Vest-Agder, X. Rogaland. M. Olsen. Under medverknad av A. Liestøl. 1954. Kildeskriftfondet, Oslo.

Nordhagen, P.J. 2003. Stavkyrkjene. I Brekke, N.G., Nordhagen, P.J. \& Lexau, S.S. (red.). Norsk arkitekturhistorie. Frå steinalder til det 21. hundreåret, s. 89-120. Samlaget, Oslo.

Norrøne bokverk $n r$. 35. 1940. Forsvarstale for kong Sverre mot bispane. Det norske samlaget, Oslo.

Næss, J.R. 1970. Melding om unders $ø$ kelse av folkevandringstidsgravgjemme på Jelsa kirkegård, Suldal (Jelsa s. og p.), Top.Ark, Arkeologisk museum, UiS.

Olsen, M. 1926. Ættegård og helligdom. Norske stedsnavn sosialt og religionshistorisk belyst. H. Aschehoug \& co., Oslo.

Robberstad, G. 1969. Omsetjing av Gulatingslovi, Norrøne bokverk 33. Samlaget, Oslo. 
Rønneseth, O. 2001. Gard og gjerde. Faser i utviklingen av Jarens naturlandskap. Erling Skjalgssonselskapet, Stavanger.

Sandnes, J. og Stemshaug, O. (red.) 1997. Norsk stadnamnsleksikon. Samlaget, Oslo.

Sawyer, B. \& Sawyer, P. 1993. Medieval Scandinavia. From conversion to Reformation ca. 800-1500. University of Minnesota press, Minneapolis, London.

Skattematrikkelen 1647. X. Rogaland fylke, Fladby, R. \& Gjermundsen, J.O. (red.). Norsk lokalhistorisk institutt, Oslo, 1978.

Skeiseid, A. 2007. Seks kyrkjestader i Rogaland. Ein arkeologisk analyse av kyrkjestader i indre og ytre deler av Rogaland. Upublisert mastergradsoppgave i arkeologi, Universitetet i Bergen.

Skre, D. 1984. Gård, kirke, bygd og sogn. Magistergradsoppgåve i arkeologi, Universitetet i Oslo.

Skre, D. 1995. Kirken før sognet. Den tidligste kirkeordningen i Norge. I Lidén, H.-E. (red.). Møtet mellom hedendom og kristendom i Norge, s. 170-233. Universitetsforlaget, Oslo.

Skre, D. 1998. Herredømmet. Universitetsforlaget, Oslo. Smedberg, G. 1973. Nordens första kyrkor. En kyrkorättslig studie. CWK Gleerup, Lund.

Smedstad, I. 1988. Etableringen av et organisert veihold $i$ Midt-Norge i tidlig historisk tid. Varia 16. Universitetets oldsaksamling, Oslo.

Solhaug, M.B. 2001. Middelalderens døpefonter i Norge. Vol. II. Acta Humaniora. Universitetet i Oslo.

Solli, B. 1996. Narratives of Veøy. An investigation into the Poetics and Scientifics of Archaeology. Universitetets Oldsaksamlings skrifter, ny rekke, nr. 19, Oslo.

Spejlborg, M. B. 2014. Anglo-Danish Connections and the Organization of the Early Danish Church. Contribution to a Debate. www.networksandneighbours.org (sist tilgjengeleg 25.05.2015) www.snl.no (sist tilgjengeleg 24.05.2015) Steinnes, A. 1930-33. Gamal skatteskipnad, 1-2 (Avhandlinger utg. av Det Norske Videnskapsakademi i Oslo, II. Hist.-Filos. Klasse, 1930, No. 1 og 1933 No. 3). Oslo.
Statsarkivet i Stavanger: Ryfylke sorenskriverembete. Pantebok nr. 9, 1853-1859, fol. 25a-26a, gnr. 38 i Jelsa herad (no gnr. 137 i Suldal kommune) (utskrift).

Steinnes, A. 1974. Styrings- og rettsskipnad i sørvest-Noreg $i$ mellomalderen. Samlaget, Oslo.

Særheim, I. 1987. Person- og stadnamn fortel. I Johnsen, E.B. (red.). Vårt eget språk 2, s. 268-343. Aschehoug, Oslo.

Særheim, I. 1996. Kleppkyrkja 1846-1946. Klepp sokneråd, Kleppe.

Særheim, I. 2014. Stadnamn og sentralitet i eit jærsk jordbrukssamfunn frå jernalderen. I Kristoffersen, E.S., Nitter, M. \& Pedersen, E.S. (red.). Et Akropolis på Jceren. Tinghaugplatået gjennom jernalderen. AmS-Varia 55, s. 49-62. Arkeologisk museum, Universitetet i Stavanger.

Sør-Reime, G. 2003. Mellomalderminne i Rogaland. AmSSmåtrykk 73, Stavanger.

Try, H. 1991. Kva skattematrikkelen ikkje fortel. Om grupper som fall utanfor. I Fladby, R. \& Winge, H. (red.). Den eldste matrikkelen. En innfallsport til historien. Skattematrikkelen 1647, 2. utgave, s. 38-43. Norsk lokalhistorisk institutt, Oslo.

Øye, I. 2002. Landbruk under press 800-1350. I Myhre, B. \& Øye, I. (red.). Jorda blir levevei 4000 f.Kr.-1350 e.Kr., Norges landbrukshistorie I, s. 215-414. Samlaget, Oslo.

\footnotetext{
Noter

' I omsetjing: «Sjelemessedagen til Ingebjørg Kåredotter er tre netter etter krossmesse [6. mai]. Kvar den mann som ser desse runene, syngje Pater Noster for sjela hennar. Gud hjelpe dei som gjer det» (NlyR III:I53, I56).

${ }^{2}$ Den eldste av to lovredaksjonar av Gulatingslova. Olavsteksten inneheldt lova slik ho var til II63 (Robberstad 1969:9).

${ }^{3}$ Den andre staden var Avaldsnes ved Karmsundet (Helle 200I:77).

${ }^{4}$ Desse har det ikkje lukkast meg å få kartfesta, då det ikkje finst skriftleg materiale som dokumenterer kor desse har lege.

${ }^{5}$ Landskylda i laupar smør er rekna ut etter samhøvet I pund korn $=4$ vetter

$=24$ spann; I laup smør $=3$ pund $=72$ merker; I pund tak $=4$ vetter $=24$

spann; I pund korn $=I$ laup smør $=2$ huder $=3$ pund tak $=6$ bollar tjøre (Skattematrikkelen X:10, Lillehammer 1970:120).

6 I 1620 vert kyrkja kalla Soledal (hoffued) kiercki (Grågås:/l0).

${ }^{7}$ Den yngste av to lovredaksjonar av Gulatingslova. Magnusteksten byggjer på

Magnus Erlingssons lovrevisjon frå tida nærast etter II63 (www.snl.no).
} 